MILE BOGOVIĆ

\title{
BILJEŽNICA ILI KVADERNA SENJSKOG KAPTOLA IZ 17. STOLJEĆA
}

Mile Bogović

Gospićko-senjska biskupija

Senjskih žrtava 36

HR 53000 Gospić

mile.bogovic@inet.hr
UDK: 930.253:2(497.5Senj)"17"

Izvorni znanstveni članak

31.07.2019.

U Biskupskom arhivu u Senju nalazi se rukopisna knjiga prihoda Senjskog kaptola iz 17. stoljeća. Pisana je glagoljskom kurzivom i latinicom. Iz knjige se mogu pratiti društvene i crkvene prilike u tom biskupijskom gradu, u vrijeme kada je senjsko-modruški biskup boravio u slobodnom dijelu Modruške biskupije, a Senjska biskupija spala na jednu (senjsku) župu kojom upravlja kaptol. Krajem istoga stoljeća Senju kao biskupijskom središtu porast će važnost jer će se biskup vratiti u nj, a njegova jurisdikcija protegnut će se na široki prostor koji je oslobođen od Turaka.

Ključne riječi: knjiga prihoda, Senjski kaptol, Biskupski arhiv

\section{Uvod}

Senjska biskupija postojala je još početkom 5. stoljeća. U vrijeme Velike seobe naroda gubi joj se trag. U srednjemu vijeku njezin spomen nalazimo prvi put 1169. godine. Otada je Senj bio biskupsko sjedište punih 800 godina. Naime, 1969. godine osnovana je Riječko-senjska nadbiskupija i biskup je preselio u Rijeku. Najteža vremena bila su 16. i 17. stoljeće. U prvom od njih biskup je rijetko boravio u Senju. Oko 1620. jednakopravno su sjedinjene Senjska i Modruška biskupija, ali je cijelo stoljeće biskup boravio na području Modruške biskupije. Na prijelazu iz 16. u 17. stoljeće Senj je spao samo na jednu (senjsku) župu jer njezin biskup, poznati Markantun de Dominis, kaže da izvan gradskih zidina biskupija i ne postoji. Veliki dio područja došao je pod tursku vlast, a ostali dio nije bio nastanjiv. Tek pri kraju stoljeća mogle su župe u Brinju i Otočcu razviti redovnu pastoralnu aktivnost. Uz ta sva središta, javlja se i Sv. Juraj kao župa, kojom su upravljali kanonici Senjskog kaptola. Kaptol je također, vodio 
brigu o katedrali koja je tada bila u gabaritima današnje srednje lađe i trećine današnjeg njezinog svetišta.

Nakon što je 1602. senjski biskup Markantun de Dominis premješten za splitskog nadbiskupa, Senj dugo nije dobio biskupa. Kada ga je dobio u osobi Vincenza Martenija (1613. - 1617.), ovaj je malo dana proboravio u svojoj biskupiji. Molio je poglavare da mu dopuste boraviti u Rijeci. Tek s njegovim nasljednikom Ivanom Krstiteljem Agatićem (1617. - 1640.) uspostavlja se barem donekle redovna uprava. No, Riječanin Agatić, i nakon preuzimanja Senjske i Modruške biskupije, ostao je u rodnome gradu. U Senju je uz katedralu bio prostran biskupski dvor, ali su ga uskoci zapalili, ljuti na biskupa Markantuna de Dominisa kojega su smatrali svojim neprijateljem. Cijelo stoljeće biskupski dvor nije se bio nikada tako obnovio da bi se moglo u njemu normalno boraviti. Nalazio se iza svetišta katedrale.

Ni Agatićevi nasljednici - Mariani, Francisci, Smoljanović, Čikulin, Dimitri i Glavinić ${ }^{1}$ nisu učinili znatniji pokušaj da se nastane u Senju. Uglavnom su boravili u Bakru tako da je to mjesto dugo slovilo kao biskupsko središte. Zadnji od njih, Sebastijan Glavinić, boravio je u Rijeci i na Trsatu. Svaki biskup imao je svoj stan i svoju kancelariju ondje gdje je boravio. Zato iz toga vremena imamo malo sačuvanog arhivskog gradiva. U biskupiji nije bilo nekih pastoralnih inicijativa. Tek s Agatićem započinje crkvena obnova u duhu smjernica Tridentskog sabora koji je rad završio pola stoljeća prije.

Dakako, sve je to imalo loše posljedice na biskupijsku organizaciju i administraciju. Upravni poslovi su se posebno umnožavali nakon što je u vrijeme biskupa Glavinića (1689. - 1697.) oslobođen široki prostor i dan na upravu njemu kao senjskom biskupu.

Senj je u 17. stoljeću imao oko 2000 stanovnika. Pastoralna skrb bila je u rukama kaptola. Jedan od kanonika bio je župnik. Prvi biskup koji se trajno nastanio u Senju bio je Senjanin Martin Brajković (1698. - 1703.). Bilo je to nakon Bečkoga rata (1683. - 1699.) u kojemu je Senjska biskupija povratila svoju jurisdikciju do prijašnjih svojih granica, a njezin je biskup dobio na upravu i mnogo šire područje. Brajković je obnovio biskupski dvor i uspostavio normalnu biskupijsku organizaciju i administraciju. ${ }^{2}$

U 17. stoljeću u Senju bila su dva samostana. Franjevci observanti imali su nedaleko katedrale crkvu sv. Franje i samostan; ostali su ondje do pred kraj 18. stoljeća. Njihov samostan je 1807. preuređen u biskupijsko sjemenište. Nedaleko

\footnotetext{
${ }^{1}$ O svakom od tih biskupa v. M. BOGOVIĆ, 2017, 98-109.

${ }^{2}$ M. BOGOVIĆ, 2017, 109-110.
} 


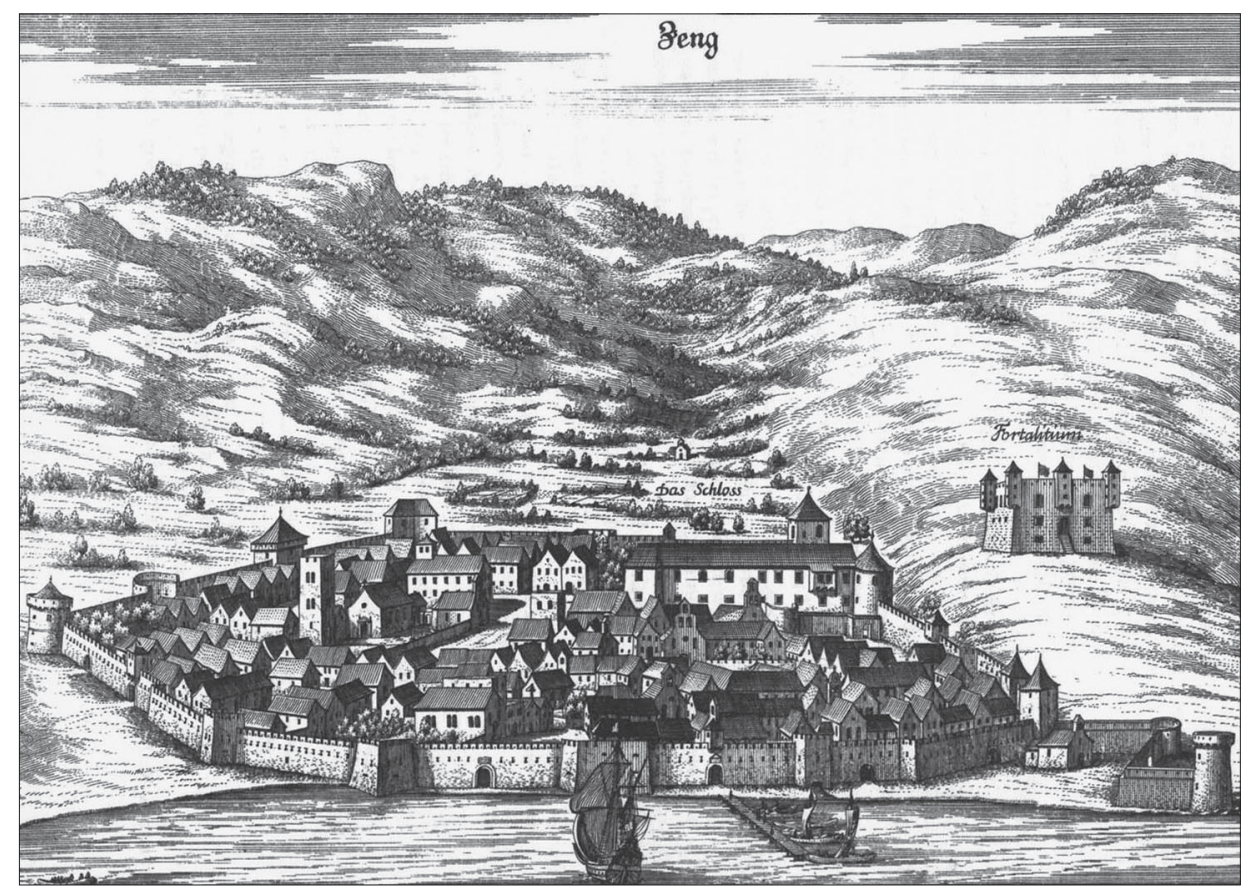

S1. 1. Veduta Senja (izvor: Johann Weikhard Valvasor: Die Ehre des Herzogthums Krain, Ljubljana, 1689.)

"Morskih vrata" bila je crkva sv. Nikole i dominikanski samostan. U 17. stoljeću i franjevci i dominikanci su malobrojni - dvojica ili trojica u svakom samostanu. Biskup Martena (1617.) piše da su to više svratišta nego samostani. Dominikanci su u drugom desetljeću 17. stoljeća napustili samostan. Biskup Agatić pokušao je u taj samostan dovesti članove svoga reda, augustince, ali je samostan ostao uskoro i bez augustinaca. ${ }^{3}$ Godine 1634. doveo je onamo pavline, koji su ostali do ukinuća reda 1786. Nedaleko gradskog ulaza s kopnene strane bila je crkva Sv. Duha i uz nju svratište ili gostinjac koji se često naziva i bolnica. Gostinjac je bio na brizi Grada i Bratovštine Duha Svetoga. Zbog nedostatka sredstava i ta je bolnica životarila. Od bratovština poznate su nam u to vrijeme još tri: Sv. Krunice, Sv. Tijela i Sv. Antuna.

Od crkava uz katedralu, dvije samostanske crkve i crkvu Svetoga Duha, bilo je još manjih crkava: sv. Ivana Krstitelja, Majke Božje od Arta, sv. Marije Magdalene, sv. Antuna Opata, sv. Roka, sv. Jurja, sv. Ane, sv. Mladenaca, sv.

\footnotetext{
${ }^{3}$ M. MEDVED, 2015, 443-452.
} 
Martina i sv. Vida. U blizini sv. Roka bila je krajem 17. stoljeća kapela Majke Božje. Nema podataka gdje je točno ona bila. Brigu o kapelama vodili su kanonici u skladu s ustaljenim običajem, a Glavinić je odredio kome od njih pripada briga za koju crkvu. ${ }^{4} \mathrm{Uz}$ spomenute crkve bile su vezane razne nadarbine koje ipak nisu redovito bile dostatne za potrebe uzdržavanja. Biskup Glavinić je svakom kanoniku stavio na brigu jednu od spomenutih crkava, osim onih koje - kao samostanske i gradske - ne pripadaju redovnoj biskupijskoj upravi.

Senjski kaptol i senjska župa imaju svoju Spomenicu koja je pisana tek poslije Drugoga svjetskog rata. Kaptolski dio pisao je 1946. godine kanonik Matija Glažar. Glažar je pritom, koristio sve što je do tada pisano o Kaptolu, a koristio se u manjoj mjeri i arhivskim gradivom koje se nalazi u Biskupskom arhivu u Senju. Dodao je na kraju tekst o žaknima, redovnicima i o Bogoslovskom učilištu. ${ }^{5}$ Nakon toga, Spomenica je vođena kao župna spomenica. Najprije je to učinio župnik Josip Banić, od 1947. do 1963. (114-121), a onda župnik Josip Frković od 1963. do 1970. (121-184). Frković je prilagao tekstove iz tiskovina, a neke prepisivao. Uz to je lijepio fotografije s raznih slavlja. ${ }^{6}$ Nakon toga ova Spomenica nije nastavljana ni kao župna. Župnici su počeli voditi drugu spomenicu.

O Senjskom kaptolu pisali su svi koji su se bavili poviješću Senjske biskupije. Prvi se time opširnije pozabavio Daniele Farlati u svom monumentalnom djelu Illyricum sacrum. U četvrtom svesku toga djela nalazi se i povijest senjskih biskupa, odnosno Senjske biskupije. ${ }^{7}$ Manojlo Sladović se dosta služio arhivskim gradivom iz Kaptolskog arhiva pri pisanju svoje knjige o biskupiji. ${ }^{8}$ Poslije njega, tim pitanjem bavio se najviše Josip Burić. Od mnogo skupljenog gradiva tek malo je objavljeno u njegovoj doktorskoj disertaciji koja je tiskana u Gospiću nakon njegove smrti. ${ }^{9}$ Vatikanskoj biblioteci ostavio je u četiri sveska veći dio gradiva koji se odnosi na povijest Senjske biskupije. Sve je to kopirano i nalazi se u arhivu Zavoda sv. Jeronima u Rimu. Tu je sada glavnina Burićeve pisane ostavštine, a manji dio se nalazi u Zavičajnoj knjižnici u Gospiću. Burićevim objavljenim i neobjavljenim radovima koristio sam se u

${ }^{4}$ Arhiv Hrvatskog državnog arhiva Zagreb, Protokoli 15, f, 8v.

${ }^{5}$ Spomenica, 1-107. Čini se da je zadnje tri stranice pisala druga ruka.

${ }^{6}$ Frković je bio župnik do 1984., ali nije nastavio Spomenicu, vjerojatno zato što je tada na molbu pomoćnog biskupa Josipa Pavlišića započeo albume za svaki od 10 dekanata u nedavno uspostavljenoj Riječko-senjskoj nadbiskupiji. Taj dio radio je uglavnom na bolesničkom krevetu. O tom njegovom radu pisao sam u riječkim Zvonima (1987, br. 3, 8).

${ }^{7}$ D. FARLATI, IV, 1769, 114-163.

${ }^{8}$ M. SLADOVIĆ, 2003, 167-189.

${ }^{9}$ J. BURIĆ, 2002, posebno 58-69. 
niže navedenim knjigama i člancima. U novije vrijeme, među ostalim kaptolima, Ante Gulin prikazao je i Drnjslo kaptol. ${ }^{10}$

Senjski kaptol je od svojih početaka igrao važnu ulogu u životu biskupije, napose senjske župe. Vjerojatno je osnovan kada i biskupija, ali prvi poznati spomen nalazimo o njemu u statutu iz godine 1340. godine. Bio je veoma prisutan u srednjem vijeku, ne samo u Senju nego i izvan granica Senjske biskupije. Do 1333. biskupe je birao kaptol, a potvrđivao ih splitski metropolit.

Nakon te godine senjske biskupe imenovao je izravno papa. Biskupi su bili stranci, većinom Talijani. Prijelaz na ovu drugu praksu zbio se nakon smrti biskupa Jurja, kada je (1332.) kaptol izabrao svoga biskupa, Bernarda, a papa poslao svoga, augustinca Ivana iz Pise. Nakon dugog otpora, kaptol je morao popustiti. U to vrijeme reguliraju se odnosi između biskupa i kaptola, donose se kaptolski statuti. Statuti Kaptola (oko 1340.) opisuju njegova prava i dužnosti. ${ }^{11}$

Najviša dostojanstva u kaptolu bila su: arhiđakon (arhižakan), arhiprezbiter (arhiprvad) i primicer (primancer). Broj kanonika bio je u skladu sa Statutom koji je donesen još 1340., tj. dvanaest, no nije ih uvijek bilo toliko. U vrijeme biskupa Markantuna de Dominisa, kada je cijela biskupije spala na jednu - senjsku župu, bilo je u Senju samo šest svećenika, ali i tada biskup u izvješću u Rim navodi da treba biti dvanaest kanonika. ${ }^{12} \mathrm{U}$ vrijeme biskupa Dimitrija (1684.) situacija je bolja pa se broj povećao na deset. ${ }^{13}$ Taj broj postao je neka norma, iako je, prema riječima biskupa Dimitrija, na sinodi u Bribiru zaključeno da broj senjskih kanonika treba biti spušten na osam. ${ }^{14}$

Imenovanje dostojanstvenika ovisilo je o mjesnom biskupu i svjetovnom patronu. Kada je arhiđakon Mihovil Božičević 1495. svoje arhiđakonsko pravo prenio na Petra Jakovčića, nastao je spor pa se Mihovil utekao papinskom legatu Ursu de Ursinisu koji je odobrio Mihovilov postupak, ali time nije načelno riješio pitanje imenovanja arhiđakona. Nakon smrti Silvestra Bedričića 1512., novog arhiđakona birali su kanonici zajedno sa senjskim sucima i plemićima. Navodi se da je to stari običaj. Izabran je Ivan Mikulanić. Nemamo nekih jasnih podataka kako je tekao izbor budućih arhiđakona, ali se to za 17. stoljeće može vidjeti iz Bilježnice ili Kvaderne.

Za izbor arhiprezbitera (arhiprvada) znamo iz spora koji je nastao 1515. Tada je kaptol, podržan od Općine, izabrao za arhiprezbitera Jurja Bartolovića, prebjega

\footnotetext{
${ }^{10}$ A. GULIN, 2008, 311-327.

${ }^{11}$ M. BOGOVIĆ, 1988, 15-28; A. GULIN, 2008, 312-314, 317-322.

${ }^{12}$ M. BOGOVIĆ, 2003, 117.

${ }^{13}$ M. BOGOVIĆ, 2003, 131.

${ }^{14}$ Arhiv HAZU IId 125, 21-22; A. GULIN, 2008, 315-317.
} 
iz Skradina, dok je upravitelj Senjske biskupije, modruški biskup Šimun Kožičić Benja, imenovao na to mjesto svoga kandidata, kanonika Nikolu de Vitisa. Kožičić je svoje pravo osnivao na prijašnjoj praksi, jer znamo da je još 1460. senjski biskup Nikola podijelio Senjski arhiprezbiterat kanoniku Petru iz Drage.

Primicera i ostale kanonike birao je sam kaptol u skladu sa Statutom. To je potvrdio kaptolu i kralj Ferdinand 18. prosinca 1527. U Bilježnici se često spominje prvadnik jer je on bio zadužen za gospodarstveno poslovanje kaptola. Njemu je bio na službi santiz. Obveze prema kaptolu trebale su se podmiriti do sv. Mihovila (29. rujna), a idućeg dana, na dan sv. Jeronima, bila je sjednica kaptola na kojoj se analizirala prošla poslovna godina i planirala iduća.

Biskup Hijacint Dimitri je uz gornje kaptolske dostojanstvenike, dodao i čast prepozita (prošta). Prvi je 1681. imenovan Stjepan Božić. Nastala je nejasnoća kome pripada prvo mjesto u kaptolu, arhiđakonu ili prepozitu. Ona je riješena u vrijeme reformi Josipa II. kada su kaptolska dostojanstva usklađena s ugarskom praksom pa od tada imamo: prepozita, lektora, kantora i kustosa. Ujedno je ukupan broj kanonika smanjen na šest. Tu strukturu kaptol je sačuvao do danas.

Ekonomski kaptol je dobro prolazio u vrijeme kada je funkcionirao sustav crkvene desetine. Nedostatak desetina, nastojali su riješiti kraljevi i lokalna vlastela. Knez Nikola Frankopan odredio je 1426. da se kanonicima i prebendarima senjske crkve daje svake godine 60 zlatnika, za što su oni bili dužni svaki dan u zoru pjevati jednu misu na čast Majke Božje za njega i za njegove pokojne. Tu obvezu on je prenio i na svoje potomke. Takvu obvezu prihvatili su poslije i drugi svjetovni gospodari koji su preuzeli na sebe i crkveni patronat. Godine 1480. čini to Matijaš Korvin, 1496. kralj Vladislav, a godine 1544. kralj Ferdinand. Sva ova tri kralja nalažu da se kanonicima (a Matijaš kaže "i biskupu") godišnje 50 zlatnika za mise pokojnih Frankopana isplaćuje od prihoda gostionice Kneginja u Senju. Zanimljivo je da se ta gostionica tako dugo održala i to pod istim imenom.

U 17. stoljeću Senjski kaptol zamjenjuje u Senju i biskupa, a također upravlja Senjom, jedinom slobodnom i organiziranom župom. Uz tu župu, donekle funkcioniraju samo još župe Otočac i Brinje, ali u neredovitim prilikama. Inicijative za pastoralnu djelatnost u unutrašnjosti, koliko je to bilo moguće, također idu preko kaptola. U Liku je krenuo kao misionar, senjski kanonik i brinjski župnik Marko Mesić, a senjski kanonici, naročito Domazetović i Ručić, bili su veoma aktivni u Lici kod poučavanja i pokrštavanja preostalih muslimana. ${ }^{15}$

${ }^{15}$ O Senjskom kaptolu u 18. stoljeću v. J. BURIĆ, 2002, 58-69. 
U 17. stoljeću spominju se sljedeći ${ }^{16}$ kanonici:

1) Abobus, senjski arhiđakon. Misi se za njega u mjesecu travnju.

2) Gabrijel Kristofor Aichelberg, imenovan je 1678. kanonikom.

3) (Ivan) Bajs (Weiss), kanonik 1674., saborski zastupnik 1681., sudjeluje u biranju novog arhiđakona 1682. Spominje se i dvije godine kasnije. Godine 1715. je opat Sv. Križa u Senjskoj Dragi.

4) Matija Belić, "plovan i kanonik crikve senjske" oko 1600. Biskup Bonaventura podijelio mu je 1589. ispražnjeno kanoničko mjesto.

5) Mihovil Bodlović je 1665. župnik u Otočcu, 1670. je kanonik senjski. Umro je 1701.

6) Juraj Bogut(ić), arhiđakon, ima svoju kuću u Senju. 1582.je arhiprezbiter senjski, 1592. izabran za arhiđakona, na toj službi je također 1602. i kao takav je kapelan sv. Ane uz katedralu. Iste godine bio je kod Markantuna de Dominisa na Rabu. On je tada i generalni vikar. Godine 1596. bio je pod Klisom gdje je ranjen i zarobljen, otkuda ga je trebalo otkupiti. Dana 19. listopada 1598. gradski oci daju otvoreno pismo da mu se pomogne.

7) Marko Bonifacio, kanonik i arhiprezbiter. Glavinić ga 1691. obvezuje da treba ići u Liku kada na nj dođe red; kao kanonik ima na brizi kapelu sv. Roka. Umro je 17. veljače 1730. u 82. godini.

8) Stjepan Božić, imenovan je 1681. prvim prepozitom kaptola. Bio je saborski zastupnik, 1684. je lektor, 1689. je arhižakan i generalni vikar.

9) Petar de Buffalis 1681. je kancelar biskupa Hijacinta Dimitra.

10) Matija Celović, kanonik senjski 1665., kaptol ga je izabrao 1669. za kancelara, 1676. je i biskupski vikar. Bio je dobar prijatelj s Vitezovićem. Bio je arhiđakon senjski 1692. te ima na brizi kapelu sv. Jurja. Umro je 14. veljače 1713. u 73. godini.

11) Petar Cvitić, 1665. spominje se kao pokojni kanonik senjski.

12) Ivan Franjo Čolić 1694. je senjski župnik. Nakon odreknuća Martina Brajkovića, Glavinić ga 11. veljače 1696. imenuje "ob peritiam linguarum" senjskim kanonikom. 1709. imenovan je primancerom, a 1713. postaje arhiđakon nakon smrti Matije Celovića.

${ }^{16}$ Najpotpuniji popis nalazi se u u Spomenici (str. 56-59). Taj popis popunio sam podacima iz Bilježnice te osobnim popisom koji vodim o svim svećenicima bivše Senjske i Modruške biskupije. Svoj popis napravio sam koristeći rukopise Josipa Burića i spise iz Biskupskog arhiva u Senju. U ovomu zadnjem dijelu mnogo mi ja pomogla ravnateljica Sakralne baštine u Senju Milena Rogić. 
13) Vinko (Vicko) Čolić 1582. je arhiđakon senjski. Na njegovo mjesto 1592. izabran je za arhižakana Juraj Bogutić. Umro je 1611.

14) Juraj Čop imenovan je 1691. kanonikom, a iduće godine spominje se i kao senjski župnik.

15) Mihovil Desantić, spominje se 1665 . kao plovan i kanonik senjski i kao biskupijski provikar. 1682. je opat Sv. Križa u Senjskoj Dragi, a 1683. je kao arhižakan na sinodi u Bribiru. Godine 1689. pokrstio je u Perušiću 44 obitelji s 246 duša.

16) Marko Domazetović, 1687. je kapelan u Otočcu, 1689. radi u Lici, 1692. je župnik senjski i na brizi ima kapelu sv. Magdalene. Umro je 1730. u 82. godini života.

17) Juraj Flurić (Frulić), kanonik senjski 1665. Godine 1671 svoju imovinu oporučno ostavlja kaptolu. Tada je bio i župnik u Krmportama.

18) Juraj Homolić, Senjanin, 1692. ima na brizi kapelu Sv. Duha, 1693. zaređen za svećenika i odmah postao kanonik. Kao opat Sv. Križa bio je sukonsekrator biskupa Pohmajevića.

19) Dr. Toma Hreljanović, kapitularni vikar nakon smrti biskupa Petra Marijanija. Senjski kanonik je 1665. Preminuo je 1681.

20) Pavao Jurišić (Jurašić), 1674. imenovan je sakristanom. Biskup Čikulin imenuje ga 1679. primicerom, što je ponovio i Dimitri 1685. Godine 1684. je generalni vikar; 1692. ima na brizi crkvu BDM blizu sv. Roka.

21) Komsa (Chomsa) Lovranjanin, 1688. je opat Sv. Jurja, postavlja karlobaškog župnika i prisvaja si vlast na cijelom Podgorju.

22) Matija Marinčić, kanonik senjski 1665.

23) Pop Marko Mesić izabran je 1678. za senjskog kanonika kao brinjskižupnik, na mjesto Nikole Vladkovića, ali u službu nije nastupio radi misionarenja po Lici. Umro je u Karlobagu 1713. U Brinju su ga zamjenjivali senjski kanonici Ivan Ručić i Marko Domazetović.

24) Pavao Mihovičić, spominje se 1614. i poslije. Prema vizitaciji biskupa Dimitrija, on je 1684. pokojni. ${ }^{17}$

25) Ivan Mikulanić, arhiđakon, odlikovan 1607.

26) Anton Miletić, 1641. je arhižakan.

27) Dominik Miletić, 1651. je arhiđakon, naredne godine i vikar. Godine 1654. istražuje spor između Petra Zrinskog i crikveničkih pavlina glede

${ }^{17}$ Arhiv HAZU IId, 125, 18. 
crikveničke luke. Pokopan je u crkvi sv. Franje gdje si je 1641., još za života, napravio grobnicu.

28) Pavao Moderčin, 1634. je kancelar biskupa Agatića.

29) Stipan Pribinović, kanonik senjski 1679. Biskup Čikulin mu je dao opatiju Sv. Jurja i istoimenu župu, što je izazvalo 1682. prosvjede kaptola kojemu pripada župa, a opatija pripada općini Senj. Dio u kaptolu imat će kad se sporazumi s kaptolom.

30) Petar Radović (Radojević), kanonik 1669. Biskupski notar kod dekreta imenovanja bio je Pavao Ritter. Umro je 1678.

31) Ivan Ručić imenovan je od Dimitrija kanonikom 1681., na mjesto pokojnog dr. Tome Hreljanovića. Godine 1689. radi u Lici, a 1691. postavlja ga Glavinić za generalnog vikara.

32) Ručić Luka, senjski kanonik 1670. Ima svoju kuću u Senju.

33) Juraj Stipšić, spominje se 1658.

34) Stuzorčić (?) Vinko, kanonik u Senju 1682.

35) Mikula Vlatković, arhižakan i kanonik senjski 1665., vikar i arhižakan 1669. Umro 1678., a na njegovo mjesto izabran Marko Mesić.

36) Grgur Vrinjenin bio je 1663. župnik u Otočcu, kao kanonik senjski spominje se 1665 .

37) Nikola Župičić (Supičić), kanonik 1582. Pod Klisom je 1596. ranjen i zarobljen. Nakon otkupa, gradski oci u Senju objavljuju 1598. otvoreno pismo da se njemu i Jurju Bogutu pomogne.

Za 17. stoljeće nemamo podataka da je Senjski kaptol posjedovao neke zemlje od kojih bi imao prihode. Svakako da je uloga vjerodostojnog mjesta bila vezana uz neki dohodak. Prije toga neki vlasnički odnos imala je biskupija prema dobru Krasno i prema Prokikama. Provalom Turaka taj odnos više nije postojao, djelomice zbog opustošenja, a djelomice zbog naseljavanja pravoslavnih Vlaha (Prokike).

Kaptol je u 16. i 17. stoljeću vodio brigu i o vjernicima prema turskoj granici. Zato je nastala praksa do sredine 18. stoljeća da svećenici u Brinju i Otočcu Senjskom kaptolu daju polovicu prihoda. Kaptol je vodio brigu i o novostečenim područjima u vrijeme Bečkoga rata (1683. - 1699.). Do tada je Senjska biskupija bila praktički svedena na grad Senj, a Modruška na Vinodol (koji je tada obuhvaćao područje do Rječine). Jednoga od kanonika biskup je imenovao svojim zamjenikom (vikarom). Ta praksa bila je i prije 17. stoljeća. 


\section{Kaptolske knjige}

Vladimir Kraljić objavio je popis glavnih spisa i knjiga senjskog Biskupskog i Kaptolskog arhiva do 1800. godine. ${ }^{18}$ Od ukupno pet navedenih knjiga Senjskog kaptola, prva nosi naslov Syllabus Archivi Cathedralis Capituli Segniensis u kojemu su popisani glavni kaptolski spisi do spomenute godine.

Kraljić je složio pronađene kaptolske spise u četiri kutije. U svom popisu spisa Kraljić nije išao redom koji je u tom kaptolskom popisu (Syllabusu) jer svi tu navedeni spisi nisu sačuvani, a pronađeni su neki koji tu nisu ni registrirani. Svoj popis naslovio je Regesta spisa Kaptolskog arhiva Senj (1272 - 1800). Ima i tu popisanih dokumenata koji se ne odnose na kaptol. Prvi spis koji se odnosi na kaptol datira iz 1450. godine (br. 4). Na 17. stoljeće odnose se samo spisi iz prve kutije od br. 49 do 66. Iako je o kaptolu riječ i u nekim spisima biskupijskog arhiva, ipak se može reći da je sačuvano malo gradiva od bogate djelatnosti Senjskog kaptola.

\section{Kaptolska bilježnica ili Kvaderna}

Drugoj po redu knjizi Kaptolskog arhiva Kraljić nije uspio odrediti ime i vrijeme nastanka. Pod br. 2 registrirana je knjiga kojoj početke stavlja u 1463. godinu, a naziva je: Knjiga zapisnika sjednica Stolnog kaptola senjskog te raznih kaptolskih prihoda, zakupa, zakladnih misa i sl." ${ }^{19}$ Ovdje sam tu knjigu nazvao jednostavno Bilježnica Senjskog kaptola. Toje isto što kod drugih kaptola nazivaju "kvaderna", negdje su to "datja i prijetja", negdje "liveli". Nisu takve knjige sadržavale uvijek istu materiju jer nisu ni svi kaptoli imali jednake nadležnosti i prihode.$^{20}$ Redovito tu nisu zabilježeni važni službeni dokumenti, nego oni koji su važni za rješavanje tekućih pitanja kaptola. U tom siromaštvu arhivskog gradiva, Bilježnica je najvažniji svjedok vremena života i rada Senjskog kaptola. U njoj je zabilježen i senjski govor te u dobroj mjeri i cjelokupni senjski crkveni i svjetovni život.

${ }^{18}$ V. KRALJIĆ, XX, 234-271. Arhivski materijal sređen je do godine 1800, a regesta svega sređenoga materijala objavio je Vjesnik Historijskog arhiva Rijeke i Pazina (XX, 231-299; XXI, 311-350; XXII, 165--201). Još prije toga objavio je u istom Vjesniku svoj: Sumarni prikaz današnjeg stanja i sadržaja Biskupskog i Kaptolskog arhiva u Senju (XVI, 287-291).

${ }^{19}$ V. KRALJIĆ, XX, 2322-233. Kraljić je kao naslov stavio "1463", kao da je tada započeta knjiga. Zatim nastavlja: Knjiga zapisnika sjednica Stolnog kaptola senjskog. Poslije ću razjasniti o čemu se zapravo radi.

${ }^{20}$ A. BADURINA, 1984, 1-176. 
U sačuvanoj Bilježnici (Kvaderni) spominje se postojanje stare kvaderne $(59 \mathrm{v})$, ali nam se ona nije sačuvala. Nije nam se sačuvala nijedna stara bilježnica, nego samo dio one (glagoljske) iz koje su šezdesetih godina prepisani podaci i ona koja je prepisana latinicom tih godina. Jedna i druga, i ona pisana glagoljicom i ona pisana latinicom, uvezane su u jednu Bilježnicu u kojoj su pomiješani listovi pisani na oba pisma. U Kvaderni ima tekstova koji su nam se sačuvali samo na glagoljici. Sve ono što je pisano nakon prijepisa, pisano je latinicom. Ima također tekstova koji su pisani i glagoljicom i latinicom. Neke od njih donijet ćemo ovdje paralelno. Nemamo sigurnih podataka otkad je u Senjskom kaptolu bilo prepisivanje iz starih bilježnica u nove. Moguće da onaj broj "1463." znači upravo početak takvih glagoljskih bilježnica. Nažalost, one stare bilježnice nisu se čuvale i sačuvale jer nisu imale praktičnu vrijednost.

Osim u četiri slučaja (navedena na kraju), u Bilježnici se ne nalaze ugovori koje je kaptol sklopio s pojedincima o najmu kuća. ${ }^{21} \mathrm{U}$ pojedinim slučajevima ti ugovori ili "inštrumenti" se spominju. ${ }^{22}$ Bilježnica je vjerojatno bila u rukama santiza, a pravni spisi, poput ugovora i oporuka, čuvali su se u posebnoj "škrinjici". ${ }^{23}$ Ugovorena strana nije dobivala cijeli ugovor, nego samo potvrdu ili "cedulu" na kojoj su bili samo glavni podaci (usp. 60r). Kako su ti ugovori izgledali, možemo vidjeti na kraju bilježnice (75rv, 76v, 77rv). Bilježnica ima ukupno 77 listova ili 154 stranice. Od toga je 61 stranica prazna. Glagoljicom su ispisane 43 stranice, a latinicom 50. Dio latiničkih tekstova pisan je na starom papiru kao i glagoljica, a dio na tada suvremenom papiru. Iz stare Bilježnice prepisano je samo ono što je imalo neku aktualnu važnost. Tako nam ta Kvaderna donosi malo podataka iz 16. stoljeća, a još je manja vjerojatnost da je sačuvano nešto starije. Malo je također, podataka koji se odnose na 18. stoljeće, što znači da ona tada nije bila redovito u uporabi.

U Bilježnici je prvenstveno popisano ono od čega je kaptol imao neki prihod. Tu su prihodi od iznajmljenih kuća i od zakladnih misa. Kaptol je posjedovao i više kuća u Senju koje je davao u najam, a još je više bilo kuća u Senju čiji su korisnici na temelju nekog ugovora bili dužni davati kaptolu određenu daću. To se u Bilježnici vodi pod imenom "liveli".

Glavnina prihoda bila je od misa. Na prvom mjestu to su konventualne mise. $U$ ono vrijeme nije bilo tzv. koncelebrirane mise kada više svećenika

${ }^{21}$ Kako su ti ugovori izgledali, vidi se iz sačuvanog primjerka od 2. svibnja 1582. kojim Katerina Lucković i Margarita ud. Živković ostavljaju kaptolu dvije kuće u Senju, a kaptol preuzima obvezu misiti dvije konventualne mise po njihovoj nakani (KAS I, br. 37. Usp. i br. 44).

22 "kako se u inštrumentu uzdrži" (v. Bilježnica, 20r. Usp. i 75rv, 76v).

23 "kako kazuje testament u skriniczi kaptolskoj" (Bilježnica, 18v) 
suslave (koncelebriraju), nego je svetu misu uvijek služio samo jedan svećenik, a svi drugi su bili na misi. Konventualna kaptolska misa je ona kada jedan kanonik misi, a drugi članovi kaptola imaju neku službu u misnim obredima ili su jednostavno nazočni na misi.

Osim konventualnih, kanonici su imali i zakladne mise. Pojedinci ili udruge mogu ostaviti nekoj crkvi ili svećeničkoj udruzi (kaptolu) određeni iznos iz kojega se u skladu s voljom zakladnika u određeno vrijeme ili na određenom oltaru (crkvi) služi sveta misa, a služitelj dobiva za to nagradu.

Platežno sredstvo u glagoljskim tekstovima su libre, a u latiničnim soldini.

\section{Bilježnica sadržajem:}

Napomena: sve što je pisano normalnim slovima i brojevima u tekstu je na latinici, a što je pisano kurzivom, to je u tekstu na glagoljici. Masnim slovima su autorovi naslovi.

\section{Kaptolski poslovi}

2r: 5.VII 1665. Nakon smrti biskupa Petra Marijanija Senjski kaptol izabire kapitularnog vikara Tomu Hreljanovića.

9r: 27. kolovoza 1667. Mješovita komisija rješava neki imovinski spor.

1rv: 30. rujna 1670. Kaptol senjski izabire za pravadnika Mihovila Desantića. 4r: 6. svibnja 1671. Ostavština popa Jurja Flurića.

11v-12r: 18. veljače 1672. Popis najamnine za zadnje dvije godine.

5r -6r: 30. rujna 1674. Reizbor pravadnika Mihovila Desantića i neke odredbe. 12v: 6. oktobra 1674. Pogodba kaptola i arhižakna.

14r: 13 Xbra 1674. Oporuka Mikule Vlatkovića

1. Kuće u kaptolskom vlasništvu: $2 \mathrm{v}-3 \mathrm{r}, 15 v-17 v$, $59 \mathrm{rv}$.

2. Liveli $18 r-20 r, 38 \mathrm{rv}, 61 \mathrm{r}-62 \mathrm{v}$ Nadarbine oltara stolne crkve: $13 r v, 42 \mathrm{vn} 43 \mathrm{v}$

3. Mise

a. Konventualne: $20 v-24 v$ 25r-28v, 34r-36r, 39r-41v, 45v-46r

b. po mjesecima:25r Envar, 26v Fervar, 26r Marač, 44v April, 44r Maij, 28r Jun, 28v Julej, 27r, Avgušt, 27v Setember, 25v Oktobar, 30r Novembr, 30v Decembar

\section{Nadarbine}

5. Kaptolski križevi 33rv, 6 .

6. Kaptolski obračuni: $7 \mathrm{v}$ (popis nekih prihoda), 9v (1670. neke takse), 8rv, 10rv (1676. popis prihoda), 37v. 58v, 59r, 60r, 63r.

7. Pravni spisi ili "inštrumienti" $75 r-76 v, 77 v$. 


\section{Biljě̆nica po listovima:}

f 1rv: 30. rujna 1670. Kaptol senjski izabire za pravadnika Mihovila Desantića 2r: 5.VII 1665. Nakon smrti biskupa Petra Marijanija Senjski kaptol izabire kapitularnog vikara Tomu Hreljanovića.

2v-3r: 30. rujna 1669. iznajmljuju se neke kuće

4r: 6. svibnja 1671. Ostavština popa Jurja Flurića

$4 \mathrm{v}$ : prazno

5rv-6r: 30. rujna 1674. Reizbor pravadnika Mihovila Desantića i neke odredbe. 6v-7r: prazno

$7 \mathrm{v}:$ Jedna stranica popisa nekih prihoda

8rv: Popis prihoda 1676.

9r: 27. kolovoza 1667. Mješovita komisija rješava neki imovinski spor.

9v:1670. neke takse koje određeni trebaju podmiriti.

10rv: 29. rujna 1676. popis prihoda.

11v-12r: 18. veljače 1672. popis najamnine za zadnje dvije godine.

12v: 6. oktobra 1674. pogodba kaptola i arhižakna.

$13 r v$ (Početak glagoljice) Na vrhu stranice piše 1463. To je latinicom navedeno na 42v, što ondje dolazi pod naslovom: To su dote Oltara kisu u Segnskoi stolnoi Crikui. Ovdje je samo mali dio teksta sačuvan. Kod sv. Magdalene ima na kraju više teksta nego u latinici.

14r: 13 Xbra 1674. Oporuka Mikule Vlatkovića

15v-17v: Tosu kuće kapitulske vlašće.

$\mathrm{Na}$ str. 59r nema naslova (u latinici)

18r-20r: Liveli kapitulski

20v-24v: Ovo su mise od kuventa kapitulskoga

25r-28v: (Mise po mjesecima. Naslov je u rujnu)

25r: Envar

25v: Oktobar

26r: Marač

26v: Fervar

27r: Avgušt

27v: Setember Ki dan se ima ka misa služiti

28r: Jun

28v: Julej

29rv: prazno

30r: Novembr

30v: Decembar

31r-32v: prazno 


\section{3rv: Križi kapitula ki plaćaju}

34r-36r: Mise od kuventa koga su miseca (latinica)

36v-37r: prazno

$37 \mathrm{v}$ : Računi

38rv: Liveli kapitulski

39r-41v: Mise od kuventa ostavne Capitullu Sengskom

42r: prazno.

42v43v: To su dote oltara ki su u sengskoj stolnoj Crikvi S. Marie

44r: Maij

44v: April

45r: prazno

45v-46r: Mise od kuventa

46v-58r: prazno

$58 \mathrm{v}$ : Račun

59rv: Kuće

60r: Računi

$60 \mathrm{v}$ : prazno

61r-62v: Liveli Kapitulski

63r: Računi

63v-74r: prazno

75rv: Glagoljski spisi

76r: prazno

76v-77v: Glagoljski spisi

Kaptolska Bilježnica razlikuje se od kaptolske knjige u kojoj su bili registrirani pravni dokumenti koje je kaptol izdavao kao vjerodostojno mjesto (locus credibilis). Darovnicom od 25. listopada 1392. car i kralj Žigmund dao je kaptolu pravo pečata i time otvorio jednu novu i bogatu djelatnost senjskih kanonika. Pravo pečata bilo je kaptolu potvrđivano svaki put nakon većih društvenih promjena. Tako ga 1480. potvrđuje i kralj Matijaš. Iz te djelatnosti kaptola poznato nam je da on prevodi povelje s hrvatskog na latinski i obrnuto, prepisuje stare povelje, saslušava stranke u sporu, uvodi u posjed na temelju kraljevskih darovnica, a u manjim parnicama i sam presuđuje. Takvih listina bilo je u 19. stoljeću dosta, ali su ih biskup i kanonici davali našim stručnjacima koji su ih objavljivali, a neke su se izgubile. ${ }^{24}$

${ }^{24}$ Objavili su ih Ivan Kukuljević i Đuro Šurmin, a nedavno ih je u latiničnom izdanju objavio Josip Bratulić: Hrvatske glagoljične i ćirilične isprave iz zbirke Stjepana Ivšića 1100. - 1527. I., Zagreb, 2017; A. GULIN, 1998, 340-344. 
Nije postojala neka prostorija gdje bi se kanonici zajedno sastajali. Sastajali su se samo u crkvi na molitvama i misama, a u sakristiji su održavali svoje sastanke. Sakristija iza glavnog oltara katedrale bila je i kaptolska i župna kancelarija. Postojala je za to posebna škrinjica gdje su se čuvali važniji spisi i knjige. ${ }^{25} \mathrm{Tu}$ su bile arhivske knjige i arhivski spisi. Tako kanonik Bartol Dušmanović ugovor između Kružića i Orlovčića, senjskih kapetana, unosi "v knigu naše kancelarie" i "v našu kvadernu". ${ }^{26}$

Za Senjski kaptol valja reći da su njegovi članovi u starini bili mahom svi Senjani i da je svaki stanovao u svojoj kući. Službeni spisi čuvali su se, kako je posvjedočio i biskup Markantun de Dominis u svom izvješću Svetoj Stolici 1602., u drugoj sakristiji u kojoj su se održavale i službene kaptolske sjednice. Do Drugog svjetskog rata u tu sakristiju ulazilo se lijevo od današnjeg glavnog oltara. ${ }^{27} \mathrm{U}$ toj sakristiji sačuvana je većina od starijeg sakralnog i kulturnog blaga koje se danas čuva u Sakralnoj baštini Senj.

Biskup Dimitri tuži se na kanonike i ostali kler da ne vode matične knjige. Doista je teško shvatljivo da senjske matice počinju s godinom 1706., a matice Sv. Jurja s 1695. Svakako je tomu "kumovala" činjenica da nije bilo posebnog župnog ureda, nego je svaki župnik uredovao u svojoj privatnoj kući pa je sudbina crkvenih spisa bila neizvjesna kada je uredovanje prešlo u neku drugu kuću i u ruke nekog drugog župnika.

Dimitri u vrijeme vizitacije kaptola i senjske župe naređuje 1. rujna 1684. da se kanonici ne smiju baviti trgovinom i da svi nabave nove brevijare da bude "jedan jezik, jedna maša i tako jedna slava". Neki svećenici ne dolaze na zajedničku molitvu časoslova i ne kupuju novi brevijar. "Jošće, neki hoće da officij govore dijački, a ne harvatski". ${ }^{28}$

Na prijelazu stoljeća (1493. - 1508.) kanonici vode glagoljsku tiskaru u Senju, a pojedini od njih često su senjski poslanici pred višim nadleštvima.

Bilježnica nam daje uvid kako je Senjski kaptol funkcionirao u 17. stoljeću, u vrijeme kada je biskup boravio izvan Senja i kada se Senjska biskupija uglavnom svela na područje senjske župe. Kaptolsko ustrojstvo je isto kao i u prethodnim stoljećima. Biskup je odsutan i dolazi u Senj na vizitacije, kao i u slučaju drugih župa.

${ }^{25} \mathrm{U}$ Kvaderni na f. 46 v potvrđuje se neka imovina tako da to "kazuie Testament u skriniczi Kapitulskoi" (Kvaderna, f. 46v).

${ }^{26}$ Vjestnik kr. hrvatsko-slavonsko-dalmatinskog zemaljskog arkiva, III/1 (1901.), 56.

${ }^{27}$ Čini se da je ona ostatak tornja jedne crkve koja je još u srednjem vijeku preuređena za biskupski dvor. Između dvora i svetišta katedrale bila je samo tijesna ulica na koju se početkom 18. stoljeća proširilo svetište katedrale pa se onda moglo u sakristiju ići iz samog svetišta.

${ }^{28}$ Arhiv HAZU II d 125, 17. 
To je vrijeme kada kaptol postupno napušta glagoljicu kao svoje službeno pismo i prelazi na latinicu. Najprije se javila teškoća s brojnom vrijednosti pojedinih slova. Tako na 16v stavlja se glagoljski znak za broj osam (8), ali izgleda da već tada nije mnogima poznata brojna vrijednost toga slova pa se dodatno tumači. Mogu se pratiti teškoće jer glagoljica ima za svaki glas posebni znak (slovo), a latinica nema znaka (slova) za neke glasove (foneme) kao što su č, ć, ž, š, đ. Tu se u transkripciji traže rješenja, ali nema dosljednosti. Naročito se to nesnalaženje vidi u transkripciji glagoljskog slova đerv. U bogoslužju traži se da se koriste glagoljski misali i brevijari jer se javlja tendencija da se prijeđe na latinske liturgijske knjige. U tom stoljeću objavljen je u Rimu glagoljski misal (1631.) i glagoljski brevijar (1648. i 1688.). Biskupi nalažu uporabu rimskih izdanja, a u kleru se počinju javljati otpori jer je u te glagoljske knjige iz Rima ušla ruska redakcija staroslavenskog jezika.

Bilježnica je korisna za upoznavanje pojedinih crkava u Senju i crkvenih udruga pri njima. To osobito vrijedi za katedralu. Spominju se mnogi lokaliteti tako da se može približno i iz ovog dokumenta rekonstruirati urbanistički izgled grada. U Bilježnici se spominje većina obitelji i prezimena koja su postojala u Senju.

\section{Lokaliteti}

U Bilježnici se za iznamljene kuće redovno naznačuje gdje se one nalaze. Tako dobivamo prilično jasnu sliku rasporeda tadašnjeg Senja. Imamo nekoliko naziva koji su i danas u uporabi, a za druge se može uz pomoć opisa doći do današnjeg položaja na kojim su se nalazili.

$\begin{array}{lll}\text { Brajde } & \text { Gromače } & \text { Pećnica } \\ \text { Cimiter } & \text { Kapitulska barberija } & \text { Pijavica (Pihavica) } \\ \text { Čisterna } & \text { Križ } & \text { Placa } \\ \text { Dolnji kraj } & \text { Lipica, turan } & \text { Pod urom } \\ \text { Dvori Babića } & \text { Mali zdenac } & \text { Pohustova } \\ \text { Galija } & \text { Morska vrata } & \text { Potoci (Potok) } \\ \text { Gorica } & \text { Mrtvačka vrata } & \text { Stipansko } \\ \text { Gornje mriže } & \text { Mundarićeva dražica } & \text { Sveti Petar } \\ \text { Gornji trg } & \text { Ogoreli prag } & \text { Sveto Telo, kuća }\end{array}$




\section{Senjska prezimena u Bilježnici}

Niže su navedena sva senjska prezimena koja se nalaze u Bilježnici. Ukupno ih je 251. Najviše se spominje prezime Desantić (32), potom slijede Miletić (30), Ručić (17), Hreljanović (15), itd. Iz teksta Bilježnice može se prosuditi u kojem smislu su ta prezimena relevantna. Da se neko prezime spominje mnogo puta, to ne znači da je bilo brojnije u tom omjeru od drugih. Treba voditi računa da su imena svećenika brojnija jer je to kaptolska, odnosno crkvena bilježnica. Ne može se reći da sva spomenuta prezimena pripadaju 17. stoljeću jer u misama se nekada moli za pokojne koji su davno umrli. Ipak se može reći da je u Bilježnici glavnina senjskih prezimena 17. stoljeća. Ta činjenica svakako pomaže da se procijeni i sastav senjskog stanovništva jer prezimena upućuju koliko je ostalo starog stanovništva, a koliko je došljaka i otkuda su došli.

S popisa starih plemićkih obitelji, koji je objavio Mile Magdić, od njih 31 samo se 8 ne nalazi u Bilježnicici ${ }^{29}$, a više od polovice prezimena u Bilježnici nalazi se u Grbovniku Envera Ljubovića. ${ }^{30}$ Kada se zna da su mnogi dobili grbove poslije 17. stoljeća, možemo reći da je većina plemićkog kadra našla svoje mjesto u Bilježnici. Gdje u tekstovima za svećenika piše "pop", to ne mora značiti da je obični svećenik jer su se i kanonici naslovljavali popovima. U tekstovima se pred nekim imenom nađe "gospodin" ili "gospa". To znači da su to ljudi višeg staleža, ali je teško prosuditi koliko je u tome bilo dosljednosti.

32

Desantić (1)

30

Miletić (1)

17

Ručić (1)

15

Hreljanović (Hreglanovich, Hrelyanovich, Herljanović) (1).

12

Bataljić (Battalich, Bateglic, Batalič), Pribinović (Pribanović) (2).

11

Blagaić (Blagagich), Božić (Bossich, Boscich), Daničić

Mundarić, Vlatković (6)

9

Celović, (J)Anušić, Lucković (Luković), Orso (Ursich, Oršić?) (4)

\footnotetext{
${ }^{29}$ M. MAGDIĆ, 1885, 225-229.
}

${ }^{30}$ E. LJUBOVIĆ, 2007, 204-381. 
8

Balenović (Balinović), Bilačić, Homolić, Katridarić (4).

7

Aichelberg (Ahlinberg, Ahilberg(er), Balardić, Bogut(ić), Lukačić, Lovračić, Milanes(ić), Rudarić, Škarić, Živković (9).

6

Bošković, Bunić, Fuks, Gerdović (Gergović?), Kovač(ević), Mikulanić, Mišlenović, Stanišić, Stipe(i)šić, Šarčić (Sarčić) (10)

5

Bobanić, Čolić (Chollich), Flurić (Furlić), Kotačić (Kutačić), Ljubić, Ptičić, (Prićić?), Radojević, Rupčić (Rupcijjch), Zaičić (Zoičić, Saičić, Sagcich),

Zidar, Župičić (11)

4

Abobus, Babić, Barać, Blažiol (Blasigol), Bubić, Domazetović, Fraškada (Frachada), Galičić, Jurčić, Kermčić (Krmčić), Komadina, Lasinović, Monigin, Mrav ili Hrunčić (Hromčić?), Mustafić

Petrović, Plavčić, Rub(p)ertić, Saki de (Bašan), Sestrić, Soldatić,

Spadarić, Štuz (Sztuz, Stucz), Tverdislavić, Valentinić, Veronez (26)

3

Baromić, Bedričić, Belić, Branislavić (Branisalić), Cvitić (Zvitich, Czvitich),

Čudinović, Ćorić, Ferkavčić, Jurašić (Jurišić), Juršić, Katulević (Katuglievich), Lenić, Lukić, Luskinić, Matijašević, Mavrić, Miovčić (Miossich, Mioffcich, Miošić), Nedile (Nedilja), Palčić, Pećarić, Racbolt, Rupančić (Ropančić, Rupalčić), Umilenović (Vumilenovich), Vukasović (Wkasovich) (24)

2.

Balestrelić, Bardarić, Bartulović, Batorčić, Bluščić, Bogatčević, Buneta, Čerkez, Depuntić (De Ponte?), Dragičević, Drašković, Fakinić, Gurlić, Hodak, Ihović (Ikičić), Jurlić, Jelačić, Jurmanić, Kalbar, Kalin(ić), Karin(ić), Kaur, Kervin (Hervin), Klišanin (Kgilisanin, Kalisanin), Kogniković (Konjiković), Kot, Krlić (Krglich), Kuhačević, Kukolević, Kvanić, Linard, Malatestinić, Mirković, Marinić, Oparić (Opassich?), Palotić, Paskvić, Posedarski, Radivojević, Rihtar (Rittar?), Rimanić, Sičić, Sosić (Sošić),

Spicinberger, Stoislavić, Vahtar, Valižić (Valežić), Sudarević, Veslar, Zlatarić, Zulić (51)

1

Bekanović, Bihel, Biljević, Bodlović, Bogdešić, Bonevčić, Bonifacio, Borčić, Bosančić, Bosnić, Bukovac, Buničević, Businić, Cvitanović, Drugančić, G(a)ržan, Grčić, Herhor, Hrikustan, Hrepac, Jandrić (Giandrich), 
(J)urković, Kalanević, Kleković, Klorić, Kondaković, Kotižar, Kranjac, Leng, Lukšić, Ljubićić, Malešić, Mandić, Marić, Marinčić, Marulić, Mihinić (Mikinić), Milić, Orić, Papeslo, Poljičan, Poplaković, Poropatić, Prišlić, Postolar, Radalijarić, Radić, Radojćević, Radonjić, Radučević, Rafaelić, Rajčić, Riglin, Rodinić, Rosanić (Rožanić), Rupić, Sablić, Satović, Sandalić, Simenić, Skradinjanin, Smolan, Stančić, Stropajević, Surdović, Šebić, Šikić, Šodić, Tintor, Tomašić, Turčić, Udragović (Wdragovich), Valentić, Vodopija, Vrković, Vlahović, Vranjanin (Wragnanin), Žarković (Xarkovich), Živić (Xiuich), Župić (80)

\section{TEKST BILJEŽNICE U TRANSLITERACIJI}

\section{Napomene}

U prepisivanju se autor služio metodom doslovne transliteracije, čuvajući i nedosljednosti u načinu pisanja. Zbog lakšeg razumijevanja, koristio se suvremenim rastavljanjem riječi. Sve što je ovdje pisano običnim slovima slovima u tekstu je na latinici, a što je pisano kurzivom, to je u tekstu na glagoljici. Masnim slovima su autorovi naslovi, a kurzivnim masnim slovima pisani su glagoljski naslovi koji su u Bilježnici.

\section{Kaptolske sjednice i zaključci}

Nakon smrti biskupa Petra Marijanija Senjski kaptol izabire 5. VII 1665. kapitularnog vikara Tomu Hreljanovića

$1 \mathrm{r}$

V Sakrestiji Crikvi Catedraloij Senskoi. Po svogoi Miloschi Semoguchi Bogh hotil e od ouoga svita zvati na Vikovicno Xivglengie svoga Nebeskoga Kraglestua Visokocastnogha G(ospodi)na G(ospodi)na Petra Marianna, Biskupa Nasegha Senskoga, ij administratora Modruskogha, i potom kako ie obicaij S. Concilia Tredentina, Capitull Poss(tovani) oue Catedrale Senske Crikve po obicagiu, i takaijsse Svetih Canoni, giesu se skupa sprauilli u Capitull, za uciniti Vikara Capitulara ki ima imit skerb i na S. Crikvami i na duhoune redounike suoe diocezi, i takaisse na dohodki biskupski, i da ima skerb i pasku, ta issti ki bude izbran Vikarom, imati znositi.

Po zapouidi i zuania Capitulla ij Arhixakna giesmo sui gedino billi oni kogi su mogli doiti i moraiu biti, kako Castni G(ospo)din Plovan Mihouil Desantich, Castni popi G. Matig Marincich, G. pop Juraj Frulich, G(ospodin) 
pop Gergur Wragnanin. G(ospodin) pop Mikulla Wlatkouich. Arhixakan, ne hotise doiti. Buduchi on obiskan s pismom od svegha poss(tovanog) Capitulla po k(nezu) Petru Zuitichiu, od kogha ne hoti pismo prieti i odgouaraiuchi da nechie doiti, i pismo aliti citaciu kako sse oude u ouih knigah vzdarxi saghdar ciniti

$1 \mathrm{v}$

mogla videti za vecne verovanje, ta su se ouako u ouoi quaderni zapisana, nazad pourati.

Buduchi se skantalla S. Misa od Duha Suetogha i naziuaiuch milost Duha Suetoga, mi zghora postouani Capitul gne izabran sui giednim glasom G(ospodi) na castnogha i brata nassegha canonika dohtora Tomassa Hreglanouicha za nassegha Vikara Capitulskogha, i gniemu sui giednim glasom prisixemo i obchiuiemo poslusni saghdar i u suemu dughouaniu biti.

A na to ne buduch on oudi na presentij, buduchi po nikom suomu dughouaniu possal u Glublaniu, do teh dob dokle on sam im persona doide, giesmo Vice Vikara ucinilli, castnogha G(ospodi)na Mihouilla Desanticha, plouana ij Canonika senskogaha, da gnihova milost tim vrimenom, kako zghora ijmenovano, skerb i pasku nosse. Potom sui iednim nacinom giesmo G(ospodi)nu Boghu zahualili i Tedeum Laudamuss kantalli.

$Z$ a vechie verovanie gia

pop Matig Celouich zbran

od possto(uanog) kapitulla za Cancelera

Crikue Senske pisah

\section{Kaptol senjski 30. rujna 1669. izabire za pravadnika Mihovila Desantića}

$2 \mathrm{r}$

Na ultim 7bra 1669. na dan S. Jerolima.

Buduchi se skupili u Sakrestiju Segnsku G(ospo)da kanoniczi Kapitula Segnskogha po zakonu i obicaiu za izabrati Pravadnika i za vechie uzrokou postouanogha Kapitulla.

G(ospo)din pop Nikola Wlatkouich, Vikar i Arhixakan Segnski, g(ospod) din pop Mihouil Desantich, plouan Segnski. g(ospo)din pop Matig Celouich, g(ospo)din pop Luka Rucich, G(ospo)din pop Stipan Pribinouich i ja zdoli podpisani.

Kadi sui iedino ucinise za ouo letto prauadnika Kapitulla Segnskogha g(ospo)dina popa Mihouila Desantichia.Vechie sui iedino ucinisse i dokoncasse da se od danassgnegha dneua sue kuchie kapitulske skupa in comun pomissati 
imaiu livelle, Misze od kuuenta i ostali nas dohodak kapitulski, ki dohodak da primati prauadnik togha leta.

Vechie ucinisse i dokogniasse da kighodar bi se izmed canonikou postupil kako u dohodak kapitulski prez znania prauadnikoua prieti, tako da cel misecz del ghubi prez suake protgnie.

Ja Pop Petar Radoieuich pisah

prauo po ordinu Postouanog

Capitula 1670.

\section{Ostavština popa Jurja Flurića}

$4 \mathrm{r}$.

Na 6 Maija 1671. u Sakrestij Segnskoij

Buduchi se skupilli skupa sua g(ospo)da kanonizi, kadi buduchi na prisentij g(ospo)din pop Juraij Flurich ki rece da on od danssgnegha dneva daije dohodak od Plouanie gnegoue dobrouolnim nacinom polouiczu postouanomu kapitullu, a polouiczu gnemu. A g(ospo)da canonici gnemu od suih i suakih dohodak z uanskih i nutergnih praui i stanouiti del mu datti, a da on pop Juriij nastoij Plouaniu kako i sada. ${ }^{31}$

Ja pop Juraij Flurich

tuerdim kako zgora

Pop Mikulla Vlatkouich

Pop Mihouil Desantich

Pop Mihovil Bodlouich

Pop Matig Celouich

Pop Luka Rucich

Pop Stipan Pribinouich

Pop Petar Radoieuich

\section{Reizbor pravadnika Mihovila Desantića i neke odredbe}

$5 \mathbf{r}$

Na ultim septembra 1674. na Dan suetogha Gerolima sabrase se u sakrestiu segnsku gospoda Canonici po zakonu i obicaiu nauadnomu a to za uciniti Prauadnika i za ostale potribsschine ouogha postouanogha Kapitulla u komu naidosse se:

${ }^{31}$ Juraj Flurić, spominje se 1661. kao plovan u Krmpotama (BAS, R3, 29). 
Gospodin Arhixakan pop Mikula Vlatkouich, Vikar i Plouan pop Mihouil Desantich, Gospodin Canonik pop Matig Celouich, Gospodin canonik pop Stipan Pribinouich, G. Canonik pop Petar Radoieuich i G. Canonik pop Pual Iurasich. Ka Gospoda naiperuo ucinisse i dokognasse da ioss za ouo letto bude Prauadnik Gospodin pop Stipan Pribinouich, a tako i tim puttem da sue dohodke i liuelle ouogha Postouanogha Kapitulla ima tiratti i primati, a ne zapuschiati.

Ktomu dokognasse i odlucisse da Gospodin Vikar i pop Matig Celouich imaiu u pomoch skupa biti Gospodinu Pribanouichu za istirati liuelle, fitte, i ostalo kapitulsko u dobar red postauiti, Veche odlucisse i dokognasse da od sada unapridak sue kapelle u koun(!) budu pod Postouani Kapitul, a to su imaiju i imenuiu

kapella S. Duha, S. Antona, Suetogha Roka i Suetiu Mladenczi, a u nassoij Crikui Poropaticheiu oltar, Hreglianouicheu grob, i popa Paula Mioffcichia. I tako da gospoda canonici imaiju redom massitti i nato Prauadnik ouogha letta i ki bude unapridak polak suoie ucignene priseghe prigledat, da budu oue kapelle sue obsluxeuane.

Pop Petar Radoieuich pisah

\section{Mihovil Desantić 30. rujna 1676. izabran ponovno za pravadnika}

$5 \mathrm{v}$

Na ultim septembra 1676 u Sakrestiji Segnskoij ca ie na dan S. Jerolima. Buduchi se skupili gospoda Canonici u Vichie za ucinitti Prauadnika i ostale chapitulske potribe. A to gospodin pop Mihouil Desantich, Plouan i Vikar segnski, gospodin pop Matig Celouich, gospodin pop Stipan Pribinouich i ia doli podpisani.

Kadi za ouo letto ucinisse za prauadnika postouanogha gospodina popa Mihouila Desanticha.

Veche bi dokognano da se ima ucinit cist i praui racun od fittou chapitulskih i od liuelou, da

$6 r$

G(ospo)din prauadnik ima cisto tiratti i gospodi kanonikom suoi portion dauati, i to od fitou na dan suetogha Jerolima.

Vechie da se imaiju izuiditi Misse od Chuuenta i chantati i ciniti se platiti.

Vechie da se ima suaki petak za dobrocinecze ijedna misa kantati.

Santize potuerdisse i joss za ouo letto ki su bili

D. Petar Radoieuich Canonik

kapitulski pisah 
Veche dognasse da Prauadnik sadssgni i unapridak..buduchi ima sam santuzi desetini na meri prighe dati.

Veche da ima prauadnik suaki misecz tiratti pinezi od zuognenia i mass i chanonikom dati, i ki da zaklade segure (!) more uazeti

\section{Oporuka Mikule Vlatkovića, arhižakna,}

$14 \mathrm{r}$

Na 13 Xbra 1674.

Ja Pop Mikula Vlatkovich Arhixakan Segnski s ouim moije ruke pismom i mogiom dobrom voglom ostavglam sue mogie kuchie $u$ kih sada stogim onim patom i kondicionom kako se u momu testamentu mogie vlastouite ruke uzdarxi, do (!) on ima plachiati suako letto P. Capitulu Segnskom 30 (d) mala 4 dim cetire na uauike, a zato budi duxan P. Capitul suaku nediglu giednu malu misu gouoriti a tto za dusu mogiu i moga otca i matere,

Ja pop Mikula Vlatkovich

tvardim kako sgora

\section{Kuće u vlasništvu kaptola}

\section{To su kuće kapitulske vlašćé}

$14 v$

Kuća Baromića v koi sada stoji gdn Matij Belić da iu darži zaedno s vertom do nega smerti a da iu snaži i načina i da ništr nne ne plaćadu do nega smrti; i te kuće su pri cimiteru (Novija ruka) Tu kuću da kapitul Ukačeviću(!) kad biaše pozvan na dušu pod letom 1581 (Č.H.O.A.)

Kuća v koi stoi gdn Paval Bilačić; tu takaiše dasmo da iu darži do nega smrti a da iu snaži i uživa i da iu načina a da niš ne plaća do nega smrti; a ta kuća suprot pećnici kapitulskoi a mimo ie put općinski

Kuće ke ostavi pokoini pop Vicenc Valežić kapitulu ke kuće dasmo gdnu Matiju Hrelanoviću da ie

${ }^{32}$ Naslov se nalazi na vrhu stranice 14 r. Latinički prijepis dijela ovog popisa na str. 59r nema naslova. 


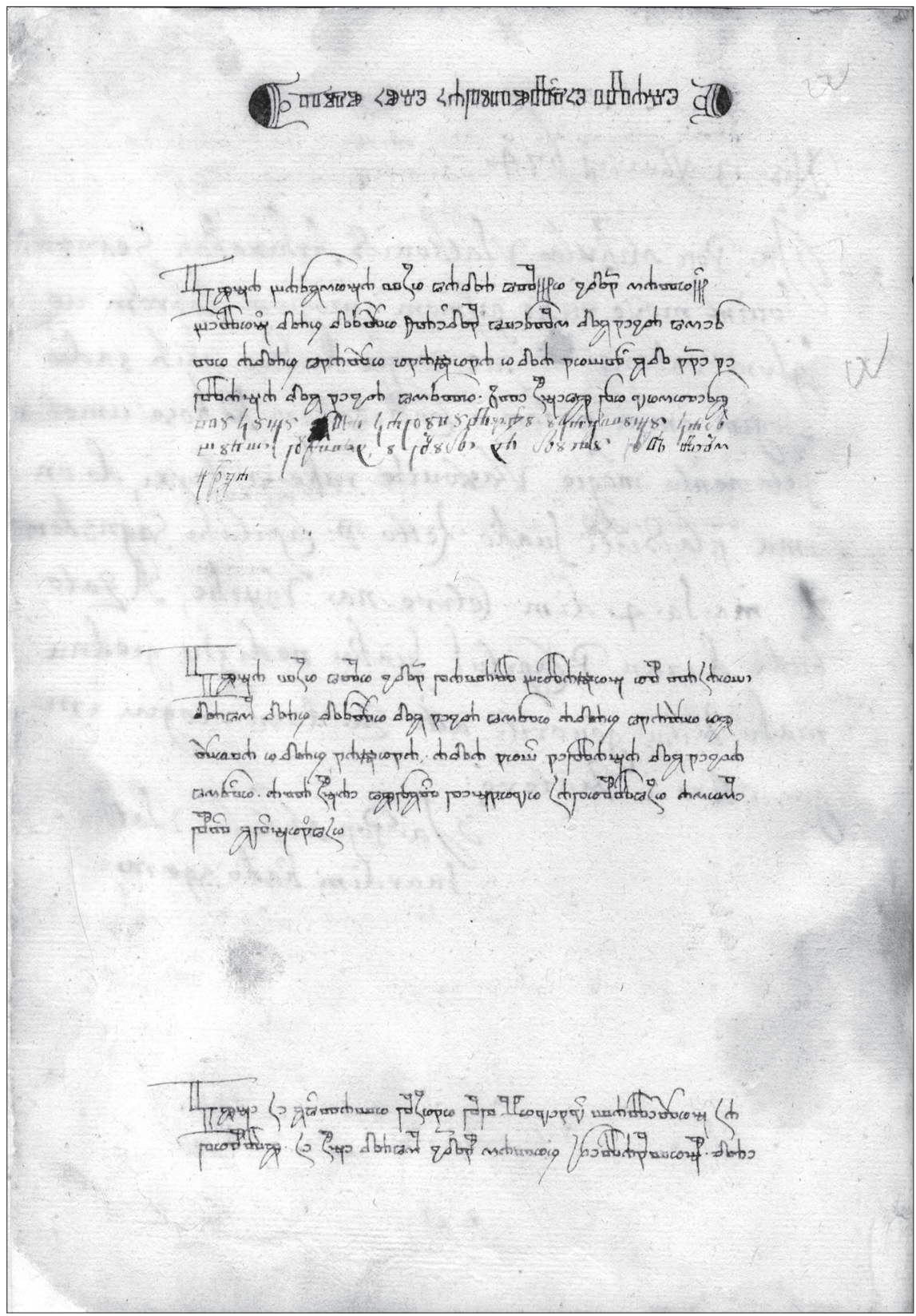

Sl. 2. Faksimil stranice 14v iz Bilježnice ili Kvaderne Senjskog kaptola iz 17. st. (izvor: Biskupski arhiv u Senju) 
drži i uživa do nega smrti, governa i načina a da ništa ne plaća do nega smrti; kuću zgora kuć meštra Jandrija Miletića.

Kuća ka ie niže kuć gdna arhižakana popa Jurja Bogutića nasuprot hiži ku e kapitul livelal Jurju Lukačiću a mimo ie put općinski. Ku mu kapitul da da iu načina i uživa do nega smrti i da ništr ne plaća do smrti.

Kuća oltara svete Katarine ka e za kapićem svetoga Ivana. I tu daše gospoda kapitul. gospodinu arhižaknu popu Ijurju Bogutiću kako i tu zgorinnu da ju guvrna i načina do nega smerti i da ništr od nne ne plaća.

(Druga ruka) ta ie kuća dana starijim Barabare, žene pokoinoga Luke Štuca, po ke smerti ima se inštrument ne starijim dan vidit stoi li u nem po iste Barbare smerti ili po ne eredov, da suprot pada pod kapitul.

$15 v$

Kuća poli mora s kamenu skalu i magazin pod nju v ki sada stoi na fit meštr Juraj Batalić i plaća na leto kapitulu libar.

Konoba pod tu zgora imenovanu kuću ku konobu sada na fit derži Petr Sablić i plaća kapitulu na leto fita o mladom letu libar.

Kuća k moru grede niže barbirie ku je kapitul založil u gospodina Mikule Župičića kada su slali k cesarovi svitlosti za provižion ku on uživa dokle ga kapitul srene s pinezi (drugom bojom) rainiši 78 (N+ znak za 8)

$16 r$

Kuća ka se zove barbirija ka e sada nafitana Rudi Mišičini kćeri i plaća kapitulu na leto fita libar 24 (I.G)

Kuća niže kuć fratar svetoga Pavla, grede k svetomu Mikuli, ku kuću prominismo s rečenimi fratri za jednu zemlju v Baški pri svetom Kuzmi ku zemlju bil je ostavil kapitulu arhižakan Abobus za misu od kuventa i kapitul da fratrom zemlju a oni kapitulu kuću i ta kuća sada nafitana Vicku Bosančiću na leto za libr

Konoba pod tu istu kuću ka e sada nafitana Luki Župičiću i plaća od nne kapitulu na leto fita libr 15 (G.I?.) 


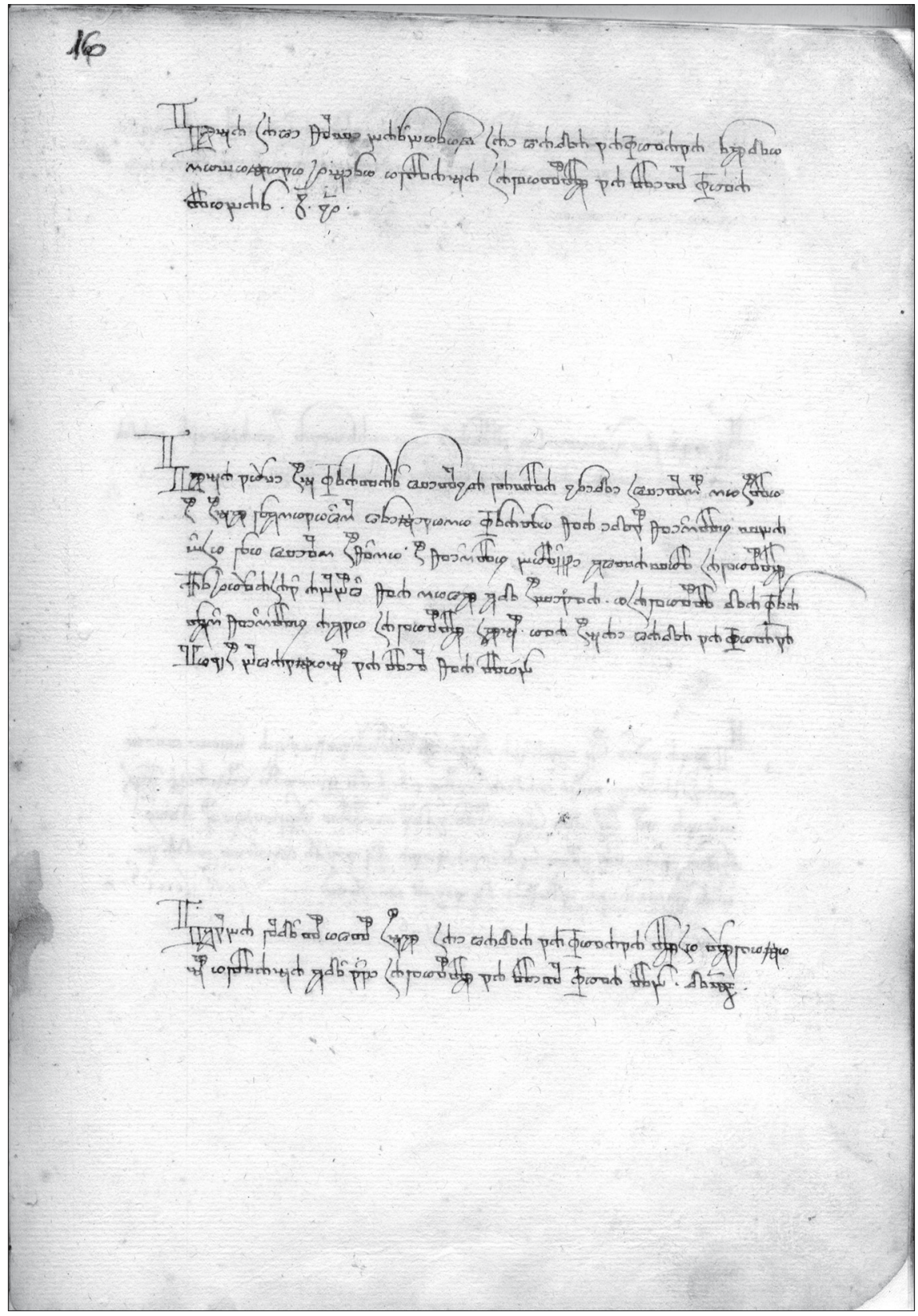

S1. 3. Faksimil stranice 16r iz Bilježnice ili Kvaderne Senjskog kaptola iz 17. st. (izvor: Biskupski arhiv u Senju) 
$16 v$

Kuća ka se zove Galija na križu v koi sada stoi na fit Vicko Mavrić i plaća kapitulu na leto fita libr 40 (K)

Kuća pri Cimiteru polag kuće Martina Kotačića sada plaća fita kapitulu na leto libar 15 (I. G.)

Kuća niže kuć sudca Dumka Milanizića više svete Magddalene v koi sada stoi na fit obitelj Tomasa Lukšića.Tu kuću da kapitul gospodinu Mikuli Župičiću da ju drži, uživa, guverna i načina do nega smerti i da ništr ne plaća od nne do nega smerti (dodano latinicim): ta ie kucha kadi e stal Bare Bataglich.

$17 r$

Kuća pri kući Baromića a sada gospodina Matija Belića ku kuću ostavi kapitulu po(ko)ini knez Bašan de Saki i v toi kućici sada stoi Anica Herhorova héi i plaća na leto fita kapitulu libar 15 (I.G.)

Kuća ka se zove Pećnica suprot kući v ki sada stoi gospodin Paval Bilačić ku kuću dasmo gospodinu Kvirinu Desantiću da peć učini do vrimena i s pati kako se u pismu ili inštrumentu uzdrži ki e meju nami učinen

(novija ruka) To ie kapitul načinil i jie sva kapitula.

Kućica pri kući svetoga Grgura oltara ili pri kući v koi sada stoi gospodin Paval Bilačić; ta ie afitana unapridak kako znaju gospoda kapitul.

$17 v$

Kućica oltara svete Katarine niže kuće ku e kapitul livelal Jurju Lukačiću, v koi kućici sada stoi Šimun Bubić i plaća kapitulu fita na leto libar 15 (I.G.)

Kuća ku ostavi kapitulu po(ko)jni Lovre Rudarić niže tisk kuć kapitulske v Rudariću dolu.

Kuća suprot kući ili Pećnici Rupovi, niže kuć ke kapitul livelal Franku Zidaru a sada ju drže ostanki Radića Kalanevića v koj kući sada stoi Juraj Kukolević.

59r (ponavlja se 61r)

Kucha Bartula Bataljića ukoi sada stogi Juanko Rihtar placha Postouanomu Kapitullu Segnskomu liuella libre tri din 3 na dan Suetoga Mihouilla; i bi 
placheno posue letto 1668. (druga ruka): va kuch ie $\mathrm{z}$ burgne strane g(ospo)dina Martina Milanesa a mimo ie put opchinski

Kucha pok. Petra Spicinbergera u koi sada stogi gnegoua chi Mare; plachia postouanomu Kapitulu Segnskomu libre dui din.Ta ie kucha suprot spitallu od ke kuche bi ucigen racun s recenom Marom xenom pok. Jue Maricha; i osta duzna po sue letto 1668 do ultim Decembra libar duanaist din. Kako nakon toga ima cedullu i bi stavglen u racun fiuret (?) koga dalla popu Iuanu Kognikovichiu.

Kuchia Sime Simina suprot Cimiteru u koi kuchi

sada stogi Gaspar Petrouich ka kucha

placha Postouanomu Kapitullu libre dui din.

i plati posue letto 1667 do ultim Decembra,

Dodatak: ou ie liuel oslobodyen, i zany plachen kapitul

$61 \mathrm{r}$

\section{Liveli}

$18 \mathrm{r}$

\section{Liveli kapitulski,}

Livel kuće v koi stoi Matij Ćolić na dolinnem trgu pri kućah fratar svetoga Frančeska; plaća Kapitulu libar 6 (ž)

(Dodano latinicom: kucia Chollicheva)

Livel kuće Vida Hrepca ka e v kuntradici niže kuć Matija Čolića; plaća Kapitulu libar 10 (I)

(Dodano latinicom: kuchia Bare Roglicanina)

Livel Martina Balardića od vrta vani zgrada ki ie bil Kapitul livelal gospodonu Frančisku Zlatariću i plaća Kapitulu so(ldina) 35 (J.G.) na Grgurevu.

Livel Jurja Grčića od vrtlaca pred kuću nihovu za kuću Jurja Umilenovića; plaća Kapitulu libru 1 (A)

Livel Depuntić na Potoci; plaća kloštr svetoga Mikule libre 2 (B) so(ldina) 5 (D) od kuće poli kuć Katridarić na Potoci. Livel meštra Jurja Zlatara; plaća Martin Žimiši- 


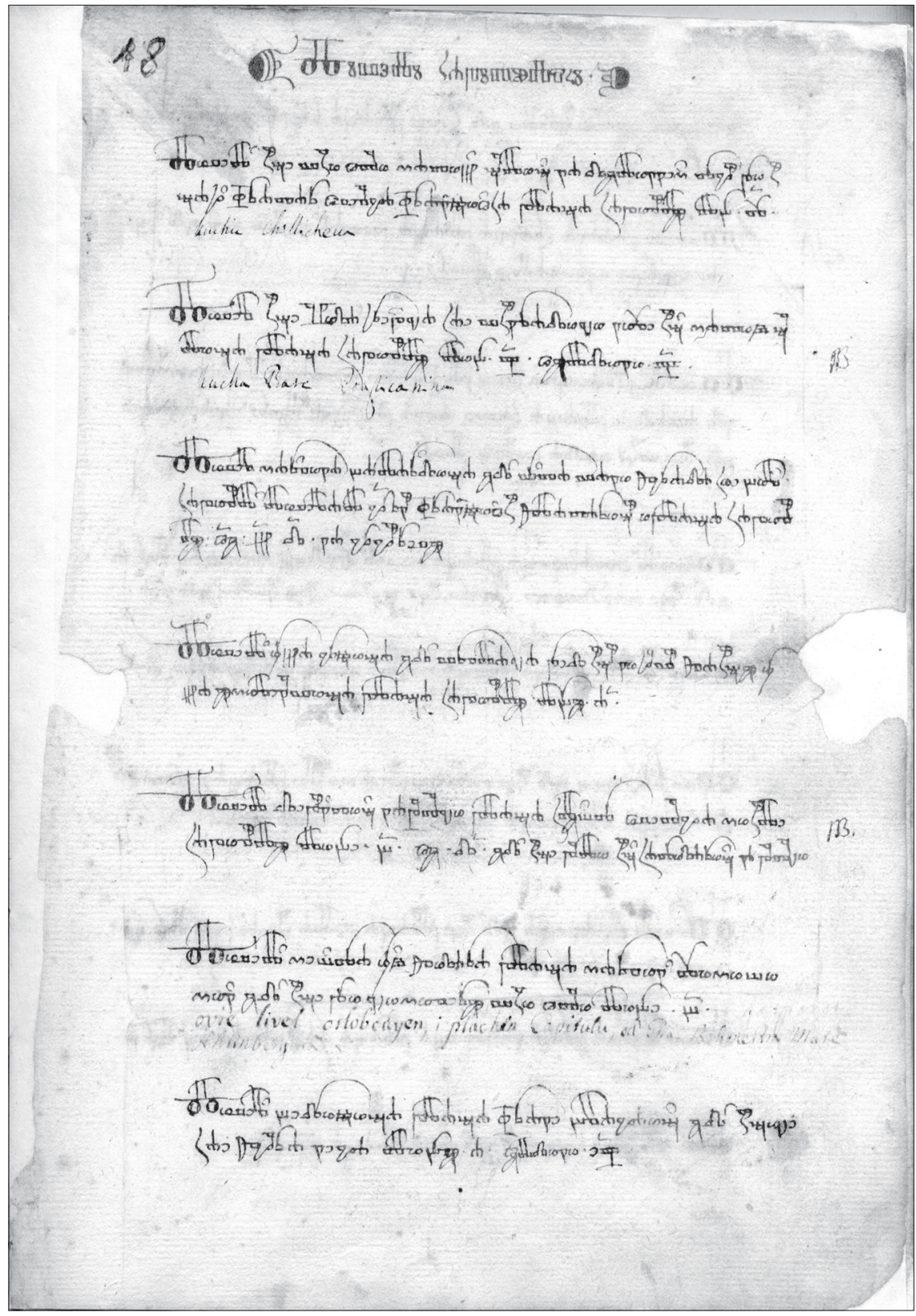

Sl. 4. Faksimil stranice 18r iz Bilježnice ili Kvaderne Senjskog kaptola iz 17. st. (izvor: Biskupski arhiv u Senju) 
min od kuće pri Cimiteru v koi stoi libre 2 (B)

Nastavlja se latinicom: ovi e livel oslobodyen i plachia Capitulu od gospodina bihmestra Mate Ahlinberga.

Livel Bedričića plaća Frane Blagaić od kuće

ka e zgora nega libru 1 (A) soldini 16 (E.I.)

$18 v$

Livel Jurjakov v dvori od kuhine; plaća Juraj Blagaić libr 1 (A)

Dodano latinicom: Placha sada.K. (40) Wule Rucich.

NB Livel Gržana Kranca plaća Petar negov sin; kuća

kae suprot špitalu libre 2 (B)

Dodano latinicom: ta ie kuchia kadi sada Skaricha stoi.

NB Livel Gurlićev ki su plaćali ostanki Vicka Smolana, a sada plaća Kate pokoinoga Lovre Lovračića

od kuće v koi sada stoi, libre 2 (B)

Livel Stančića; plaća meštr Andrija Miletić lbr 1 (A)

od kuće Mandičine ka e pri kući negovi ku su kupili od Jurka

Livel Marulića; plaća Mikula Šikić od kuće libre 2 (B)

Livel Rajčić; od kuće niže svetoga Mikule plaćaju ostanki Matija Rajčića libre 8 ča e libr osam

Dodatak latinicom: a sada derži Miho Raduceuich, pustismo na S. 2

Livel Bobanića ;od kuće plaća Jela Bobankina lbr 3 (v)

Dodano latinicom: placha sada xena Mate Bonevcicha (?)

Livel popa Petra Božanića; plaća Juraj Batalić lbr 2 (B)

Livel Ivka Ručića od trsja plaća so(ldina) 12 (B.I.)

$19 \mathrm{r}$

Livel Barića Klokvića; od kuće plaća meštar Jandrij Mile-

tić. Kuća je niže kuće Martina Pribinovića, libre 2 (B)

Dodano novijom rukom: to plaća Anton Rupertić 
Livel Lovre Rudarića; od kusa trsja plaća Grgur Orić so(ldina) 8.

Livel meštra Kerštofora Batalića; od kuće v koi stoji plaća libre 3 (V)

NB Livel Brne Cvitanovića; od kuće ka e suprot kući Jurja Baleštrelića plaća Matij Bekanović libre 2 (B) so(ldina) 10 (I)

Livel popa Martina; plaćati ima mirišće ka e v dvori popa Matka Blagaića, libre 2 (B)

Liuel Jurja Lukačića; od kuće plaća libre 2 (B)

Dodano latinicom:sada plaća Jure Desantich

$19 \mathrm{v}$

Liuel kućice pri kući Bobanić; ku sada darzi ostanki Jurgia Vomiglenouića, plaća libr. S.10

Liuel Jerke Ljubićke; od kuće zgora Lukačićeve, plaća lbr 3 (V)

Liuel kuće Martina Fraškade zgor kuće Ljubićkine, plaća lbr 5 (D)

Liuel od Duora kuće ka ie bila Dorke Bogatčevice a sada iu darži Anica Boškovićka, plaća lbre 2 (B)

Livel Anica Boškovićke; od mirišća oltara svete Katarine koioi Kapitul livela i plaća libre 2 (B)

Livel Ivana Karinića od kuće u koi stoi, niže kuće ostanak Vida Kotižara, suprot kućam ostanak Milosa Rodinića a mimo e put općinski; plaća Kapitulu libre 2 (B)

Livel Mandičin so(ldina) 20; kuća e ku sada drži Jelka Prišlićka.

Kuća ku sada drži meštar Jandre zgora kuće fratr svetoga Mikule na gornem trgu. Ta kuća biše Antačinova.

Dodatak latinicom: Ovo ie liuel oslobodyen biusi dano prečastnom Kapitulu dukat 10 od gospodina Cojberta Vida Mileticha ki su dani na interes. $20 r$

Livel kuće svetoga Kirjaka oltara; plaća Hodakovica.

Dodano: plaća gne zet Mihovil Oparić lbr 2 (B) so(ldoni) 10 (I) 
Livel Tomasa Dragićevića od kuće Loure

Rudarića; plaća 8 prvi dan agošta.

Ako dva leta ne plati da kuću zgubla s ovim pa-

tom mu e dana kako se v inštrumentu uzdrži 1601 (Č.H.A)

Dodano: učinenom i nemu danom.

$61 r$

Liuelli kapitulski pripisani iz glagolskoga na nass heruatski ijezik na 23 Jullia $1669 .{ }^{33}$

Jure Domazetouicha xena Giella placha na kuchi u koi stoij ona i gne Jure i gnie hchi Mare ka ie billa kuchia pokoine Orsichke suako letto liuella

S. 2

Takaise mirischie ko se tischi recene kuchie.

(Umetnuto: kadi e ucinil kuchiu sada Perica Dossinouich)

placha na letto liuella dim libre cetire u sue

S. 2

Luka Stucz placha na kuchu ukoi stoij liuella sako letto

S. 9

Ka ie kucha za kapijchem S. Juana

Bartula Battaglicha kuchia ku sada derxe gnegoue hchere Ante i Vicze

placha na letto na dan S. Mihouilla dim libre tri. Kuchia se derxi

kucie S. 3 od burgne strane 40 (.K.) Martina Milanesa a suprott kuchi s termuntane 40 (.K.) Andre Rupcijcha, a mimo je put obchinski

$61 \mathrm{v}$

Kucha pokoinogha Petra Spicinbergara u koi sada stoij gnegoua hchi Mare a vdoua pokojnogha Juana Skarichia plachia liuella sako letto libre dui kaie kuchia suproti Kapitullu ospitallu S. Duha u koij sada stoij Juricza

Kuhaceuicha(!)

NB Kuchia Sime Simina suprot cimiteru ukoij sada stoij i plachia Ghaspar Petrouich

sako letto luella libre dui dim bgt 2

(umetnuto: ta uech ne placha zostonani (!) dal livella libre dvi, dim bgt

(drugom rukom): oui livell plachen za vuik i postauglene pinezi na kuchu kapitulsku pri moru ie dal Burgmestar Ahilberg.

${ }^{33}$ Iz ovoga naslova može se vidjeti da se i kuće mogu staviti pod livele jer su i one "livelane", što znači dane u najam. 
Kuchia Jure Luskinichia u koi on sada stoij; plachia liuella na letto na dan S. Mihouilla libar sest dim L 6 ka se derxi kuchie s termuntane Wule Ruchia(!) a peruo ije billa Barichia Kattnichia.

Kuchia Josseffa Keruina plachia na letto liuella libre tri S 3; ka se kucha tischi kuche kapitulske ku sada derxi Mate Jurssich na korgnem(!) kraiju a mimoije putt opchinski. ${ }^{34}$

$62 \mathrm{r}$

Kuchia Matte Jurssichia plachia na letto libre tri $\operatorname{dim}$ S 3, ka ie kuchia u ghorgnem kraiju prema kuchi kapitulskoij a mimoie putt opchinski.

Miko Celouich stari plachia liuella od kuchie Cristoffola Bataglichia libre tri $\operatorname{dim}$ S. 3

Ka ie kucha zburghe od juxne strane kuchie popa Matia Celouichia gnegoua sina,

a blizu pechnicze ku sada derxi Bartul Miletich Canciler Segnski.

Miko Raduceuich plachia na letto liuella

od kuchie kase derxi s giugha kuchie pok pok. Dauanze a z burgne strane kuchie S. Duha, a mimoi je putt opchinski, dim libre liuella dui: Kako nato instrument ima.

$62 \mathrm{v}$

Kuchia u koi sada stoij knez Juan Bossich plachia suako letto post. Chapitullu segnskomu liuella libre dui dim $\quad$ S. 2 za uelikom Crikvom, ka ie kuchicza nad szkalami kako se u kuchiu gre.

Na 18 Jenuara 1673 bi dana kuchia na liuel Postouanoga kapitulla Anti vdoui pok. Petra Czuiticha a cheri Sime choge(!) za dukata cetire caije S. 24 ka ije kucha na Krizu, ku ie kuchu paruo daroualla Ane pok. Borouka ka sse kucha darzi pechnicze Patar S. Paulla s tim patom i kondicigom da gima kuchu nacinitti; ne naciniusi caije potriba da more kapitul suoiju kuchu preda se uzeti i tullikai ako ne bi na dan kako zgora suoga duznoga liuella platilla da mozi kapitul kuchiu sebi uazeti i drugomu dati.

${ }^{34} \mathrm{Na}$ dnu stranice napisano je "Kuchia Matte", što znači da je na sljedećoj stranici to prva riječ. Ipak na vrhu te stranice piše: "Eredi Juana Pribinouicha plachaiu na letto Misu od kunuenta od kuche Kate Stanisichke L 2 Misa se gima kantati Na". To je sada prekriženo. 
$38 \mathrm{r}$

Liuel Jurgia Lukacicha od kuche placha

S. 3

to je kucha ku Jure Desantich darsi.

Liuel kuchice pri kuchi Bobanich ku sada darzi ostanki Jurgia Vomiglenouicha placha

Liuel Jerke Gliubichke; od kuche zgora Lukacicheue placha.

- to ie mirische uise Jure Desanticha duora

Liuel kuche Martina Frachade zgor kuche Gliubichkine

placha

Liuel od Duora kuche ka ie billa Dorke Bogatceuice;

sada iu darzi Anica Buskouichka placha

S. 2

kadi Skradignanin stogi

Livel Anice Buscouichke od mirischia oltara S. Katarine kogoi Kapitul livela i placha

Liuel Iuana Charinicha od kuche u koi stogi nize kuche ostanak Vida Kotižara suprot kucham ostanak Milosa Rodinicha a mimo gne put opchinski placha

Dodano: kadi Millica Balenouich stogi

Liuel Mandicin S. 20 (i) kuchice ku darsi Jelka Prichichka kuchice ku sada darsi Mestar Jandre Miletich zgora kuche fratar S. Mukulle na gorgnem targu i ta kucha bise Antacinova toie kueha kadi stogitkadi sada Pilinka stogi. NB

Liuel kuche S. Kirjaka oltara; placha Hodakovicza. Placha gne zet Mihovil Opasich.

Dodano: toge kucha popa Luke Rucicha kadi sada stogi

Liuel Tomasa Dragicevicha; od kuche Loure Rudarich placha parui dan agusta. Ako ne plati 2 letta da kuchu zgubgla stim patom misec dana kako se u istrumentu uzdrzi 161 ucigenom i gne mu danom. 


\section{Konventualne mise}

\section{Ovo su mise od kuventa kapitulskoga}

$20 v$

Misa Broza Orsa; plaća Dumko Milanez od kućice pri sebi.

Dodano latinicom: to plachia Martin Milanez.

Misa Bunića; plaćaiu kuće Bunić kesu nasprot kućam kapitulskim s duorom u kih sada stoi gospodin Paual Bilačić.

Misa Lovre Rudarića od trsja; plaća Gergur Sošić

Misa Gospodina Francisca Miletića od trsja ko e u Lopici; plaća mestar Andrij (! $)^{35}$ Miletić

Misa Vicka Rupančića ku ostavi na kući svojoi kae za crikvu

Misa Matka Kota plaćaiu ostanki Vičinovi od kuće

Misa Valentinića plaća žena Ivana Urkovića od kuće niže kuće Rusinove

Misa Škaričina plaćaiu kuće Senankine za crikvu

$21 r$

Misa Gospodina Frančiska Živkovića; plaćaiu kuće negoue velike ke su pri Cimiteru nasuprot mrtvačkim vratom.

Dodano latinicom: to sada plaća Iue Ahlinberger.

Misa popa Osipa Bobanića; plaća trsje negouo koie v gromačah ko on ostavi $v$ svoiem teštamentu da pomankavši koleno negove sestre Jele trsje pada na Kapitul senski.

${ }^{35} \mathrm{U}$ latiničkom tekstu je Anton. 


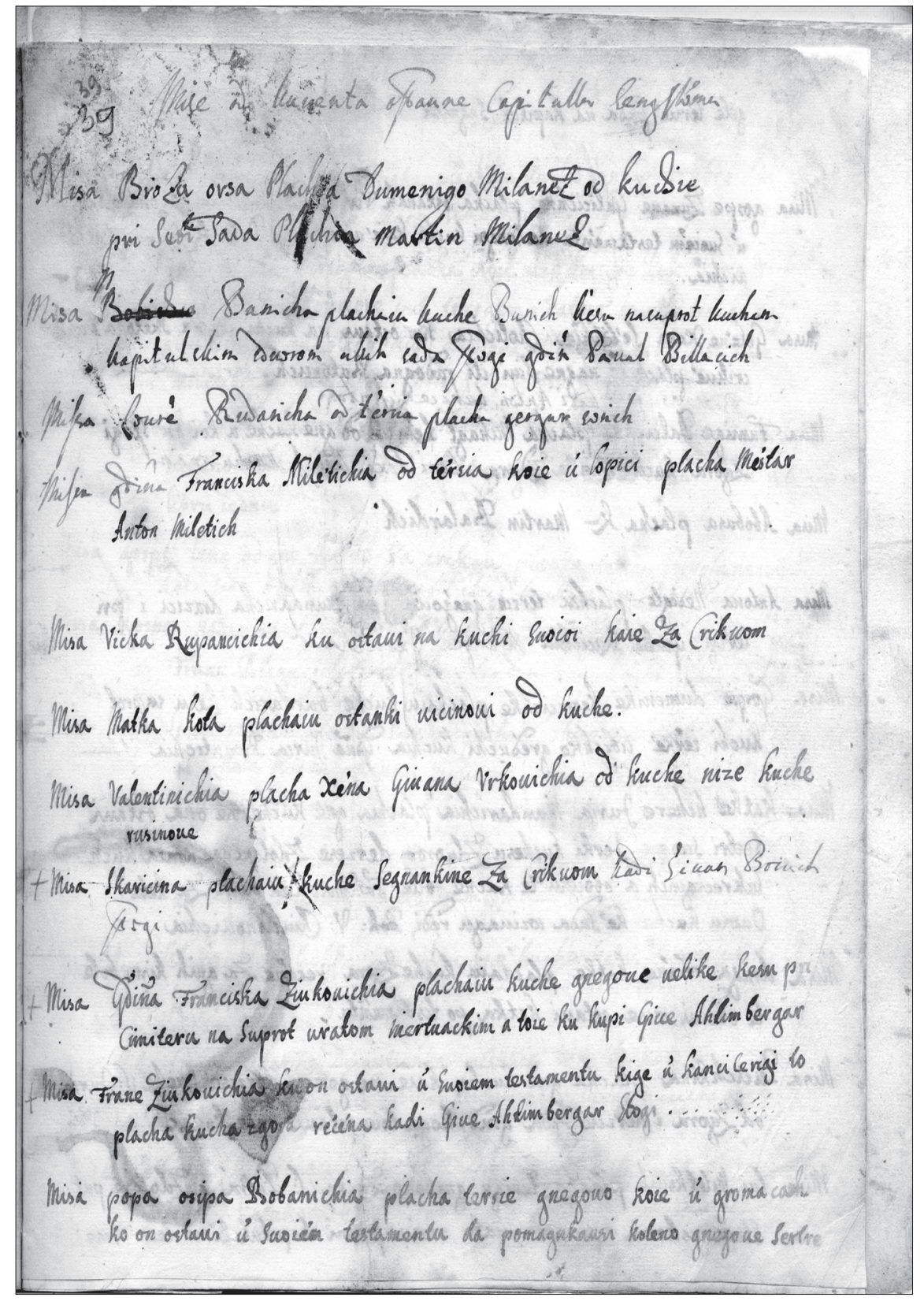

S1. 5. Latinička transkripcija stranice 39r iz Bilježnice ili Kvaderne Senjskog kaptola iz 17. st. (izvor: Biskupski arhiv u Senju) 
Misa Gospe Žuvane Galičićke; plaća sudac Virin(!) Desantić ku ona ostavi v svoem teštamentu na suojoi kući kae više kuće pokoinoga kneza Juria Luckovića

Misa Elene žene Šebesća Čolića ku ostavi na kući zgora Svetoga Duha crikue; plaćiaiu nne sini ili Radona Batorčić. Dodano latinicom: Plachia Anton Kuhaceuich, sad nyegou zet Petar Bihel placha.

Misa Fumie Palčićke; plaća Mihal Lenić od ne kuće v koi on stoi, zgora kuć Franka Zidara.

Misa Abobusa; plaća knez Martin Balardić.

$21 \mathrm{v}$

Misa Antona Nedile plaća trsje negovo pri Mundarića dražici i pri trsiu Ivke Ručića.

Misa gospe Dminke Krmčićke; plaćaiu kuće Bardarić ke su suprot kući Jerke Liubićke, gredući kućam Gospodina Juria Bogutića.

NB Misa Katke, hćere Juria Mundarića, plaćaiu gne kuće ke ona ostavi sestri suojoi Jelki $i^{36}$ kuće su s duorom i derže se z dolnega kraja kuć Lukreciinih, a oboe su te kuće bile Fakinić. Ta misa za Katku. Dodano latinicom: Ouo su kuće ke sada uziuaiu redi pok. V. Chudinouicz.

Misa druga recene Katke; plaćaiu kuće zgora recene za onih kih su bile. Te obe dvi mise ostavi Katka po testamentu.

NB Misa Ptičićkina; plaća nne kuća ka ie na Gorici; drži se kuće svetoga Juria od zgora i drži se zida gradskoga. To e ostavil Rade Kovač.

NB Mise dvi Miletkovih; plaća trsje nihovo zgora Svetoga Petra, a zdola e put $k$ Stipanskomu. Pismo ie nato meiu pismi kapitulskimi. Te se mise imaiu reći u svetoga Frančiska prez zuognenja; plaća libre tri $(V)$

${ }^{36}$ U latiničkom tekstu je Jerka. 
NB Misa Ivana Fuksa u svetoga Frančiska plaćaiu kuće negoue libre dvi so(ldina) pet $(G)$

$22 \mathrm{r}$

Misa Mustafićkina od trsja se plaća ko e niže trsja pokojnoga popa Vincenza Miletića a mimoie put $k$ trsjem i na toi misi ki trsje uživa ima staviti na oltar dva duplera a dva na grob novembra na $3(V)$

Misa popa Jerolima Katridarića plaćaiu kuće na potoci, ostanki Šebića Mislenovića libru 1 (A) a brat negov

Tomas od dobar ki su v Baški libru 1 (A)

Misa gospe Lene, od nne kuće za crikvu plaća Tomas Hrelanović. Dodano latinicom: Ovu misu prestaui na suoju kuchu Gospa Mande udoua pok. gospodina Gaspara Hrelyanouicha. NB

Misa gospe Katarine Luckovićke ku ostavi na Pohustovi i to sada plaća Frane Blagaić. NB

Misa Urse Špaderice; plaća kuća nihova ka e pri kući Baletrelićevi zdola kuće ostanak Matijca Kovača.

Dodano latinicom: sada stoij sin Pauna Klisanina, sadje oua kucha u Klare xene pok. Ivana Vlatkovicha.

Misa Jele Orsićke ku ostavi na kući ka e zgora kuć Martina Fraškade, nasuprot kućam Čeprninim.

$22 v$

Mise dvi Klare Homolićke; plaćaiu nne kuće ke su zgora pećnice kneza Frane Blagaića. Dodatak novijom glagoljicom:

To plaća pećnica kapitulska.

Č. F. P. Mrč I.B (tj. 1590. 22. ožujka)

Misa pokojne gospe Katarine Desantićke; plaća mirišće ko se zove Ogoreli prag. To ona ostavi po teštamentu.

Dodatak latinicom:

Plachaiu eredi Gerge Jurcichia (nova ruka) a sada Vule Paskuicha. 
Misa Šebića Mišlenovića plaćaiu kuće na Potoci zdola kuć Klekovićevih

NB Misa Cicina; plaćaiu ostanki Soldatić od nnih kuće ka e pri mrižah gorinnih suprot kući Jurja Janušića ali Voivodice . Dodatak latinicom: plachia Kerste Jurasich.

Misa Magdalene Lovračićke; plaćaiu nne kuće ke su zgora kloštra fratar svetoga Mikule.

Dodano latinicom: To su kuće xene pok. V.

Perice Wkasouicha .

Nova ruka: Ouu kuchu promini G. Mate Francikoua (!) s Patri

Paulini, i ti yoy dase kuchu izpod duora i kuche $\mathrm{g}$. kanonika i arcipreta popa Marka Bonifacia.

Misa Gašparinova; to e plaćal Antačine Bluščić a v teštamenti popa Baraka kuća e Kapitulu ostavlena.Tteštament je u kancileriji senskoi. To plaća kuća ku drži sada Anica Martina Posedarskoga, meiu kuću Ivana Mundarića i kuću Tomice Stanišića pod turnom Lipicu.

$23 r$

Mise tri Gospe Klare Daničihke, ke ostavi na kući ka e poli kuće Armonijine i kuć Drašković blizu zida gradskoga pri malom zdencu; jednu za brata, drugu za nevestu, a tretu za se. Dodano latinicom: To plachaiu redi Petra Danicicha, a sada Rade Radonyich.

NB Misa Jurja Mikulanića, ku on ostavi na kući suojoi ka e pod urami.

Misa Martina Balardića, ku on ostavi da plaćaiu kuće negoue ke su pri kućah Ivana Solodatića.

Dodano latinicom: To plaćaiu eredi Miletichia.

Sa strane: kucha Lengova.

Misa Gašpara Blažiola; plaća kuća negova ka e meiu kuću svetoga Jurja, ku sada derže ostanki Franića Mavrića, i meiu kućiu ostanak Vicka Stipešića .

Dodano latinicom: to plachaiu eredi popa Vicka Jelacicha. 
Misa Mare Čeprnine, ku ostavi da se plaća od kuće Ivana Pećarića nasuprot kući Jele Oršićke

Misa Mare Jablaničine, ku ona ostaui da plaća nne kuća kae polag kuće Antona Ručića zgora kuć Miletkouih.

Novija glagoljska ruka: Kate Bubićka ostaui u suoiem testamentu na suogoj kući ku sad derxi jne šć(er)ka

Mare mise jednu od kuventa i dva duplera na oltar. ${ }^{37}$

$23 v$

Misa Mikule fra Gaspara ku on ostavi da plaća kuća negoua ku sada darži Tomica Stanišić zgora kuće kae bila Jurja Flurića (!) suprot velikom zdencu.

Dodaci latinicom:

prvi: to plaćaiu eredi Pribinouicha. drugi: sada u Paue Domazetouicha, treći/ sada placha Gpspodin Paue Homolich, a sad je Antona Drugancicha, Ouie liuel plachen precastnom Kapitulu biusi dano u lettu 1730 dr: 20 misu na interesu.

Misa Jurja Šarčića ali Hrele plaća kuća kae poli kuć Jurja Kaura nalivo k papinu turnu grede

NB Misa Stane Kalinke ku ona ostavi na suojoi kući ka e meiu kućami Tomasa Hrelanouića i Barića Sestrića.

Dodatak latinicom: to plachaiu eredi Bossichia.

Misa Jage Mravove ali Tomasa Hromčića ku ona ostavi na svojoi kući kae više kuć kneza Jurja Stipšića.

Dodatak latinicom: To plachaiu Eredi sada Čerkeza.

Misa Lucie Ćorinice ku ona ostavi na kućici maloi kae bila Vicenza Luckovića za veliku crikvu pri kućah Šodića

${ }^{37}$ Tu se već miješa bosančica! 
Misa Marice Nigomerke plaća kuća nne ku Kapitul alive la Jerolimu Pribinoviću.

Nastavak latinicom: To plaća Loure Rubertić, a sad njegov sin Frane.

Misa popa Martina plaća mirišće v dvori popa Matka Blagaića

$24 r$

Misa Jurja Janušića ali Voivodice ku ostavi v svoem Teštamentu da plaća kuća negova ka e v dolinem kraiu $v$ dvori zgora Fuksoa vrta i to plaća negov zet Milos Palotić i nega hći Vicka ki kuću uživaiu; teštamentje $v$ kancileriji senskoi.

Misa Ivana Katulevića ku on ostavi na suomu tersju ko e vise svetoga Martina plaća lbr 2 (B)

Misa Marice Plavčićke ku ostaui na kući kaie poli kuće zdola Petra Zoičića plaća L 2

Mise tri Lucie Božićke ke ostavi suojom hćerom Fumijom na kući kaie kaie(!) poli kuće Se strića plaćaiu lbr 6 $N B$

Misa Anice hćere Jandrija Kotačića ku ostavi na kući suojoi kaie zgora mirišća ko se zove Opogoreli prag plaća Kapitulu lbr 2

Dodatak latinicom: Sad je ta kuća ereda Vicka Paskuicha

Nastavlja se glagoljicom ali novijom rukom:

Mise tri ke ostavi Kate Gerdovićka na kuću ka je na placi meiu kućom Baćana de Saki i kućom Svetoga Duha. Ima plaćat Kapitulu senoskom suako leto lbr 6NB Jedna misa za Sarčića na 14 avgusta Prikloni Druga za jne duše na 24 febrara Molimte Gospodi Treta za jne muža na 4 oktobra Prikloni ${ }^{38}$

\footnotetext{
${ }^{38}$ Nema u latiničkom tekstu.
} 
$24 v$

NB Mise tri, ke ostavi knez Frane Desantić jednu na ouoi kući suojoi kadi ie čisterna; a drugu na kući ka ie u Baški pri kući Bunetovoi, tretu na brajdah ke su poli Urse Mandić S ne dase plaća vsako leto Kapitulu senskomu lbr 6.

(mlađa ruka)

Misa Jele Bokine; plaćaju ostanki od Ivana Rupčića libre dvi i soldini 8 i dua duplera na pervi Majia.

Dui Mise Anice Ručićke ke ostavi na svojoi kući ka ie pri kućah Frane Blagajića na 10 Iun i 3. Octobra

\section{Konventualne mise ostavljene Senjskom kaptolu}

39r

\section{Mise od kuventa ostaune Capitullu Segnskom}

Misa Broza Orsa; placha Dumenigo Milanez od kuchi pri sebi. Sada placha Martin Milanez

Misa Bobieha Bunicha plachaiu kuche Bunich ke su nasuprot kucham kapitulskim, s duorom u kih sada stogi gospodin Paual Bilacich.

Misa Loure Rudaricha od tersia; placha Gergur Sosich.

Misa Gospodina Francisca Miletichia, od tersia koie u Lopici; placha mestar Anton Miletich.

Misa Vicka Rupancicha, ku ostaui na kuchi suoioi ka ie za Crikuom.

Misa Matka Kota; plachiaiu ostanki Vicinoui od kuche.

Misa Valentinicha; placha xena Giuana Vrkovichia od kuche nize kuche Rusinoue.

+Misa Skaricina plachiaiu kuche Segnankine za Crikuom. Dodano: kadi Giuan Borcich stogi 
+Misa Gospodina Francisca Ziukovicha; plachiaiu kuche gnegoue uelike ke su pri Cimiteru, nasuprot uratom mertuackim ,a to ie ku kupi Giue Ahlinbergar.

+ Misa Frane Ziukovicha, ku on ostavi u suoiem testamentu, ki ge u kancilerigi. Plaća kuća gore rečena kadi Give Ahlinberger stogi

Misa popa Osipa Bobannicha; plachia tersie gnegouo ko ie u gromacah, ko on ostaui u suoiem testamentu da pomagnkausi koleno gnegoue sestre

$39 \mathrm{v}$

Gele, tersie pada na Kapitul segnski.

Misa Gospe Zuzane Galicićke; placha ostanak Virina Desantichia, ku ona ostaui u suoiem testamentu na suogoi kuchi ka ie uise kuche pok. k(neza) Juria Luckouicha.

Misa Gelene xene Sebeschia Cholichia, ku ostaui na kuchi zgora Suetoga Duha crikue; placiag na gne sini ili Radogna Batorcich. Dodano: Darsi se kucha Vulle Balenouich kadi Anton Kuhacevich stogi.

Misa Fumige Palcichke; placha Mihagl Lenich od gne kuche u koi on stogi, zgora kuch Franka Zidara kadi Boxe Lenich kuchu nacinil.

Misa Abobusa; placha K(nez) Martin Balardich.

Misa Antona Nedigle; placha tersie gnegouo pri Mundarichia drazici i pri tersgi Giuka Rucichia. Dodano: Garge Jurcicha.

Misa Gospe Dumenike Kermcichke; plachaiu kuche Bardarich ke su suprot kuchi Jerke Libichke (!), greduchi kuchiam gospodina Juria Bogutichia

Misa Katke, hchere Juria Mundarichia; plachia gne kuche ke ona ostaui sestri suogog Jerki. Kuche su sz duorom, derzese z dolgnega kraia kuch Lukreciginih, a oboie su te kuche bile Fakinich. Ta misa za Katu.

Ouo su kuche che sada uziuagu redi pok. V. Chiudinouichia.

Misa druga recene Katke; plachaiu kuche zgora recene za gnih ki su bile te obadui mise, ostaui Katka po testamentu. 
Misa Pticichkina; placha gne kucha ka ie na Gorici. Derzi se kuche S. Juria od zgora, i derzi se zida gradskoga. To ie ostauil Rade Kouac.

Dodatak: kod Wuce Stropaieuicha.

Mise dui Miletkouih; placha tersge gnihouo zgora S. Petra, a zdola ie put Stipagnskomu. Pismo ie na to meiu pismi kapitulskimi te se mise

$40 \mathrm{r}$

gimaiu rechi u S. Franciska, prez zuognenia. Plachia libre tri.

Misa Giuana Fuksa u S. Franciska; plachiaiu kuche gnegoue libre dui, soldina pet. Kuche Mare Simenichke.

Misa Mustafichkina; od tersga se placha ko ie nize tersga pok. popa Vincenza Miletzichia, a mimo ie put tersgem. I na to ie misa: ki terzge uziua gima stauit na oltar dua duplera a dua na grob. Misa na 2 Nouembra. Dodano: na Stipagnski pok. Jele xena Antona Veroneza

Misa popa Jerolima Katridarichia; plachiaiu kuche na potoczi ostanki Sebicha Mislenouicha libru iednu, a brat gnegou Tomas od dobar ki su u Baski libru iednu

Misa Gospe Lene; od gne kuche za crikau placha Tomas Herglanouich. Dodano: kadi sada Anton Postolar nafit stogi; kucha ie ere (!): pok Vichka Hreglanouicha.

+Misa Gospe Katarine Luckouichke, ku ostaui na Pokustoui(!); i to sada placha Frane Blagagich (dodano: to darzi Barbara, xena Viccha Bosnicha i udoua pok. Sturogeuicha.

Misa Urse Spaderichke; placha kucha gnihoua ka ie pri kuchi Balestrelicheui zdola kuche ostanak Matigcza Kouaca. Sada stoi sin Pauna Kglisanina Jure. Dodano: sada stogi Mate Tomasich.

Misa Gele Orsichke, ku ostaui na kuchi ka ie zgora kuch Martina Fraskade, nasuprot kucham Cepergninim. Dodano: Wulle Ballenouicha. 
Mise dui Klare Homolichke; plachaiu gne kuche ke su zgora pechnicze k(neza) Frane Blagagichia. Dodatak: to su kuche kadi sada stogi .... Paue Homolich od duora i od ${ }^{39}$

Misa pok. gospe Katarine Desantichke; placha mirischie ko se zove Ogorili prag; to ona ostaui u suoiem testamentu. Gergo Jurcich derzi.

Misa Sebichia Misglenouichia; plachiaiu kuche na Potoci, zdola kuch Kglekouicheuih. Dodano nekoliko riječi i prekriženo.

$40 \mathrm{v}$

Misa Cicina; plachiagu ostanki Soldatich od gnih kuchie kaie pri mrizah gorignih, suprot kuchi Juria Janusichia ali Voiuodicze. To ie kadi Kerste Jurasich stogi.

Misa Magdalene Lovracichke; plachiaiu gne kuchie ke su zgora klostra S. Mikule;

to su kuchie xene pok. V. Perice Wkasouichia. Dodano: Sada darzi udoua pok. Franicha Ahleberga.

Misa Gasparinoua; to ie plachial Antacine Bluscich a u testamenti popa Baraka kuchia ie Kapitulu ostauglena. Testament ie u kancilerigi Segnskoi; to placha kuchia ku derzi sada Anica Martina Posedarskoga meiu kuchiu Giuana Mundarichia i kuchiu Tomice Stanisichia, pod turnom Lipiczu.

Mise tri Gospe Klare Daničihke, ke ostaui na kuchi ka ie poli kuchie Armonigine i kuch Draskouich, blizu zida grackoga pri malom zdenczu: iednu za brata, drugu za neuestu, a tretu za se; to plachiaiu redi Petra Danicichia.

Misa Juria Mikulanichia, ku on ostaui na kuchi suogoi kaie pod urami. Dodano: duor pri Cimiteru Rubcichieu.

Misa Martina Balardichia, ku on ostaui da plachiau kuche gnegoue ke su pri kuchiah Giuana Solodatichia; to plachiaiu redi Miletichia.

Prvi dodatak: od mirischia pri kuchah Iue Rosanicha zbute (!); drugi dodatak: sada darxi ... Milich.

\footnotetext{
${ }^{39}$ Nečitljiva jedna ili dvije riječi.
} 
Misa Gaspara Blazigola; plachia kuchia gnegoua ka ie meiu kuchiu S. Juria, ku sada derxe ostanki Franichia Maurichia, i meiu kuchiu ostanak Vicka Stipesichia; to plachia pop Vicko Jelacich. Dodatak: kadi Jerko Rafaelich stoij.

Misa Mare Cepernine, ku ostaui da se plachia od kuchie ka ie pri kuchi Giuana Pechiearichia na suprot kuchi Jele Vrsichke.

Misa Mare Albanicine, ku ona ostaui da plachia gne kuchia ka ie polak kuche Antona Rucicha zgora kuch Miletkouih: 40 (k).

Kate Bubichka ostaui u suoiem testamentu na suogoi kuchi ku sad derxi

$41 \mathrm{r}$

Misa Mikule fra Gaspara, ku on ostaui da plachia kuchia gnegoua ku sada darxi Tomicza Stanisich, zgora kuchie ka je bila Juria Frulichia (!), suprot uelikom zdenczu; to plachiaiu redi Pribinouichia.

Misa Juria Sarcicha ali Hregle; plachia kuchia ka ie nize kuch Juria Kaura, naliuo papinu turnu. Dodatak: toie kucha pok. Mare Satouichke, ku kupi pok pop Petar Mirkouich. Drugi dodatak: sada red sin pok. Martulana Mirkouichia.

Misa Stane Kalinke, ku ona ostaui na suogoi kuchi ka ie meiu kuchiami Tomasa Hreglianouichia i Barichia Sestrichia. To placia Iuan Boscich. Dodatak: sada plaća ... (nema nastavka!).

Misa Gage Mrauoue ali Tomasa Hruncichia, ku ona ostaui na suogoi kuchi Ka ie uise kuch k(neza) Juria Stipsichia. To plachia Mate Cerkez. Dodatak: sada derzu Marko Ihouich (?).

Misa Lucige Corinice, ku ona ostaui na kuchi malog, kaie bila Vicenza Luckouichia, za ueliku crikuu pri kuchiah Sodichia. Dodatak: miriscie pri kuchi Ane xene Juana Riglina od Crikue.

NB Misa Maricze Nigomerke; plachia kuchia gne ku Kapitul liuela Jerolimu Pribinouichiu. To plachia Loure Rubertich. 
Misa popa Martina; plachia mirischie u duori popa Matka Blaggagicha. Dodatak: to ie duor pred kuchiu S. Tella ki se darxi kuche Chudinoue.

Misa Juria Anusichia ali Voiuodice, ku ostaui u suoiem testamentu da plachia kuchia gnegoua ka ie u dolgnem kraiu u duori zgora Fuksoua vertla; i to plachia gnegou zet Milos Palotich i gnega kuche (!) Vicka ki kuchiu ostaui (!). Testament ie u kancilerigi segnskoi.

Misa Giuana Katuglieuicia ku on ostaui na suomu tersgu koie vise S. Martina; plachia S. 2

Misa Marice Plauicichke ku ostaui na kuchi ka ie poli kuchie zdolla Petra Zoicichia plachia L 2. Dodatak: toge kuchia Mihe Plaucichia kadi sada stogi xena Garge Radaliarichia (?). Drugi dodatak: pod lettom 1703 oslobodisse sudci Jakoua Kouaceuicha od ouoga liuela Giakou Kuhaceuich.

$41 \mathrm{v}$

Mise tri Lucige Bozichke ke ostaui suogom hchierom Fumigom na kuchi ka ie poli kuche Sestrichia. Plachia S. 6

Dodatak: kadi sada Jure Lukinich stogi.

Misa Anicze, hchere Jandriga Kutacichia, ku ostaui na kuchi suoiog ka ie zgora mirischia ko se zoue Ogoreli prag. Plachia Kapitulu L 2

Dodatak: to ie kuchia kadi Gargo Jurcich stogi.

+Mise tri ke ostaui Kate Gergouichka ${ }^{40}$ na kuchi ka ie na platzi meiu kuchiom Basana de Saki i kuchiom S. Duha. Ima plachiat Kapitulu Segnoskom suako leto S 6

+Mise tri, ke ostaui k(nez) Frane Desantich: iednu na ouog kuchi suogog kadige cisterna, a druga na kuchi ka ie u Baski pri kuchi Bunetouoi, treta na bragdah keli(!) ${ }^{41}$ poli Urse Mandicine; da se plachia suako leto Kapitulu segnskomu S 6

Misa Gele Bukine; plachia ostanak Giuana Rupcichia L 2i soldini 8 i dua duplera na perui Maia.

\footnotetext{
${ }^{40}$ U glagoljskom tekstu je Gerdovićka.

${ }^{41}$ U glagoljskom tekstu: ke su.
} 
Dui Mise Anice Rucichke, ku ostaui na suogoi kuchi ka ie pri kuchiah Frane Blagagichia: na 10 octobra (dodatak: to ie kuchia kadi /nečitljivo ime i prezime/ stogi.

Misa popa Gergura Saicichia na Gergureuu; a to ostaui na suogoi kuchi ka ie uise kuch Andriga Rucicha, a put opchinski kuda straza(!) gre mimo kige po turan pri uelikih vratti.

Dodatak: to ie kuchia kadi Iue Bogut stogi. ${ }^{42}$

Konventualne mise $45 \mathrm{v}$

$+\mathrm{Na}$ post S. Marie Mandalene Misa iedna za xenu pok. Mihe Ceneade (?) i zduimi dupleri na grob i zduimi na oltar.

+Na post S: Mikule misa iedna za dusu Mihe Corade z duimi dupleri na grob i na oltar ke mise iedne i druge duzni su plachati eredi pok. Mihe Corade. ke mise ostaui pok.

Mande, na trih kuchiah stecenija gnie, i gnie Gospodara kako kazuie Testament u skriniczi Kapitulskoi.

Na 20 Luija misa za erede Pokoinika Juana Pribinouicha. A to placha kucha ukoi stoij Bore Pribinouich.

Na 1 Xbra Mise tri, iedna za dusu Klare Danicichke, druga za gne bratte, treta za gne neuiste. Mise plachaiu.

46r

sada dua bratta Danicicha Juricza i Juan. A te su mise na kuchiu ka se darzi kuch pok: Jure Danicicha pri malom zdencichiu.

Na 2 Junia Mise tri za dusu Katarine Gherdouichke i gne ostanki. Plachaiu sini pok: Pere Danicicha Jure i Juan. A te su mise na kuchi ukoi oni stoie na Plazi med kuchom Basana de Saki, ka ie kucha sada Voiuode Viczka Wkasouicha i med kuchom S. Duha kadi stoij Pere Belich.

$\mathrm{Na}$ 1. Maija plaća 19 dim misu od kuventa $\mathrm{z}$ dvimi duplerima na grob, a $\mathrm{z}$ dvima na oltar. To placha k(nez) Andre Rupcich za kuchu pok. Jelle Bukine, ku sada oni uxivaiu.

\footnotetext{
${ }^{42}$ Ovoga nema u glagoljskom tekstu.
} 


\section{Mjeseci}

Mise po mjesecima (glagoljica)

Ki dan se ima ka misa služiti ${ }^{43}$

Vsaka misa od kuventa plaća libre 2

$25 r$

Envar

Klare Danićke (!) na 10., 11. i 12. Edna

Prikloni a dvi Molim te Gospodi ${ }^{44}$

Jurja Hrele ali Šarčića na Antonu. Prikloni

Stane Kalinove 21 Molim te Gospodi

Mare Baraćke na 31 Molimte Gospodi

Stane Stipšićke na 2 za muža i ženu četirimi dupleri

Stipane Komadine na 7. za nega Prikloni

$26 v$

Febrar

Homolićkina na 10. Molim te Gospodi

Šebićkina na 13. Molim te Gospodi

Gospe Kate Luckovićke na 14

Gašpara Blaziola na 14. Prikloni

Kate Gerdovićke na 24. Molim te Ora. Molimte

Mare Župićke na 3 dan S. Blaža

$26 r$

Marač

Bunićeva na 7. Prikloni

Cicina na 16. Molim te Gospodi

Misa Ikarična na 12. Prikloni. Škaričina

Martina Balardića na 19. Prikloni. Ali zjutra dan po marte

Jage Tomaša Mrava ali Hromčića na 26. Molim te

Negomrkina na 21. Molim te Gospodi

Marice Plavčićke na 23. Molim te Gospodi

${ }^{43}$ Naslov se nalazi u Kvaderni ispred rujna (september), što znači da su i tada rujan smatrali prvim mjesecom radne godine.

${ }^{44} \mathrm{Na}$ kraju naznake za misu redovito su početne riječi glavne molitve u misi po kojoj se i sama misa u kalendaru naziva (Molim te, Prikloni, i dr.). U latiničkom tekstu prije tog naziva su: Or, Ora, Orat., što je skraćenica za Oratio - molitva. To naznačuje koja je misa (Prikloni, Molim te, ... ). 


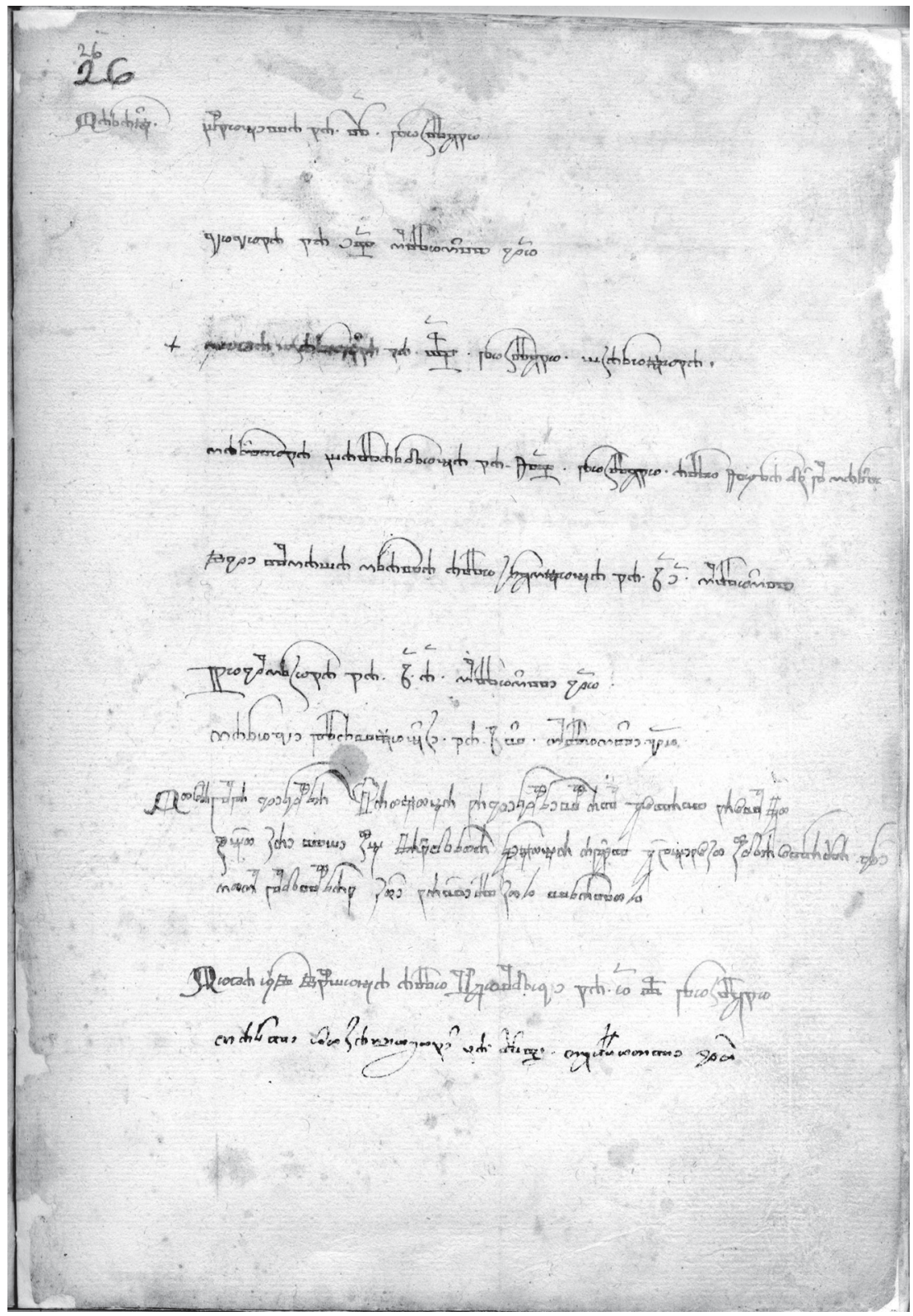

Sl. 6. Glagoljski tekst za mjesec ožujak (marač), faksimil stranice 26r iz Bilježnice ili Kvaderne Senjskog kaptola iz 17. st. (izvor: Biskupski arhiv u Senju) 
Misa popa Gergura Saičića na Gergurevu a to ostavi na svoi kući kae višse kuć Jandrija Ručića a put općinski kuda straža gre mimo pod turan ka e na vellkih vratih Misa Jurja Janušića ali Voivodice na 21 Prikloni Marte Vikavicine na 17. Molim te Gospodi

$44 v$

April

Homolićkina na 15. Pokloni

Popa Abobusa o Jurjevi. Prikloni

Fuksova na Jurjevu. Prikloni

Gošparinova zjutra dan po Jurjgevi. Prikloni

Popa Osipa najkašni aprila. Prikloni

Lucie Božićke za jnu 24. Molim te

Lucie Božićke druga za hćer na 25. Molim te

Lucie Božićke treta na 26. Za mnozih

Gospe Ladena(!) 21. Molim te

Lucie Božićke druga za hćer na 25. Molim te

$44 r$

$M a j$

Baromića na Dujmovu. Prikloni za popa

Gospe Lene na Jeleninu. Molimte Gospodi

Jurja Jurmanića ča ie Gržanoua na 24. Prikloni

Kate Mundarićeve na 27.Za mnozih

Elene Zečarice o Duhovi plaća kuća. Molim te Gospodi. Šimun Bubić

Frane Desantića na 13. Prikloni

Na 7 Popa Vicenca Bataglića, za popa

Na parvi za Bukinu. Molim te Gospodi. i to plaćia ered Iuan Rupića dva i mu? inica četiri dupleri, a to od kuće.

$28 r$

Jun

Dminke Kermčićke, prvi petak po Duhovi Molim te Gospodi

Jurlićeva ali popa Ferkavčića na 7. Prikloni za popa

Meštra Šebića Mišlenovića na 12. Prikloni

Mikule Fra Gašpara na 16. Prikloni 
Mare Jablaničine na 20. Molim te Gospodi

Frane Desantića na 24. Prikloni

Urse Branisalićke na 14. Molim te Gospodi

$28 v$

Julij

Katke Mundarićeve na 6 (e), Za nnu Molim te Gdi

Katke Mundarićeve druga, na 7 (ž), Za mnozih

Vida Valentića na 10 (I), Prikoni

Miletkovih na 22 (i b). Za mnozih u svetoga Frančiska

Miletkovih druga na 23 (i v),Za mnozih u Svetoga Frančiska

Popa Martina na dan svetoga Panteleona

Blaža Župičića na 24 (i g). Prikloni

$27 r$

Augusta

Jele Oršićke na 10. Molim te Gospodi

Galičkina na 14. Prikloni

Frane Živkovića na 23. Prikloni

Garžanova ku ostavi Rimanić na 25. Prikloni

Gurlićeva ku ostavi pop Ferkavčić na 27. Prikloni

$1594^{45}$ Kneza Jurja Mikulanića 28. Prikloni

Jivana Katulevića na 29. Prikloni

Pokoinoga Tomasa Hrelanovića na 16.

Sarčićeva na 14. Prikloni

$27 v$

Setembr

Nedile Antona na Miholu za muža. Prikloni

Magdalene Lovračićke za nпu i za ne muža

Popa Jerka Katridarića na 14. Prikloni

Ptičićkina ili Rade Kovača na 5. Prikloni

Linardova na Matijnu. Prikloni

Mare Baraćeve na dan S. Mihovilla

Vujave Komadinke na 4. Molim te Gospodi

${ }^{45}$ Godina se nalazi na margini stranice. 
$25 v$

Oktobar

Fumie Palčićke na prvi. Molim te

Spaderićkina na 6. Mollim te Gospodi

Ćoriničina na 10. Molim te Gospodi

Pokoinoga voivode Matija Tvrdislavića na 22. Prikloni

Gospe Vučice Hrelanović na 21. Mollim te

Katarina Mihinica za 29. Mollim te

Kvaničina na 31. Mollim te

Marka Gerdovića na 4. Prikloni

Frane Desantića na 4. Prikloni

Mandalene Lasinovićke na 19. Mollim te

Mihe Ručića na 19. Prikloni

+.ne...tine .nice za 20. Molim te

$30 r$

Novembar

Mustafićkina na 3 za(!). Molim te

Frančiska Živkovića na Martinu. Prikloni

Anice hćere Jandrija Kotacića 15 za(!). Molim te

Pokoine Gospe Margarite Tverdislavićke na 4. Mollim te

Kate Lasinovićke na 5. Molim te

$30 v$

Decembar

Desantićkina na večer Mikule za ženu. Molim te Gospodi

Vicka Ropančića o Mikuli. Prikloni

Miletićeva na dan sve Bibijane. Prikloni

Gospe Lucie Bartulovke na Lucijnu plaćaju kuće. Prikloni

Vice Branisalića na 11. Prikloni

\section{Mise od kuventa koga su miseca ke}

$34 \mathrm{r}$

Jenuar

Na 2 Clare Stipsichke za muxa i xenu, duplera 2

Clare Danicichke 3: parva na 10, druga na 11, a treta na 12 Jedna na Prikloni a dui Molimte 
Jurice Hregle na Antognu. Prikloni

21 Stane Kallinoue . Or. Molim te Gospodi +

31 Mare Barachke. Or. Molim te Gospodi

Stipana Komadine. Ora. Prikloni

Februar

Na 10 Klare Homolichke. Ora. Molim te Gospodi +

$\mathrm{Na} 11$ Stepana Blazigolla. Ora. prikloni +

Na 14 Kate Luckouichke. Ora. Molim te +

24 Surdouichke Kate. Ora. Molim te

Na 30 Mare Zupicichke. Ora. Molim te

Marac

Na 7 Bunicheua

Na 6 Cicina. Ora Molimte

$\mathrm{Na} 10$ Jurgia Anusicha alli Vogvodice. Ora. Pokloni

$\mathrm{Na} 21$ Nigomerkina. Ora Molim te

Na 23 Marice Plaucichke. Or. Molim te

Jage Tomasa Mraua alli Hramchichi

$(34 \mathrm{v})$

12 Martina Balardicha. Ora. Pokloni +

Misa popa Gargura Sagcicha na Gergureu, a

to ostaui na svogoi kuchi ka ie kucha Andria

Rucicha, a put općinski kuda straza gre pod turan

na vellikih vrati

Na 17 Marte Vikavicijne. Ora. Molim te

April

Na 15 Klare Homolichke. Ora. Pokloni

Popa Abobusa Gurgevi. Ora. Prikloni

Fuksova na Gurgevu. Ora. Prikloni

Gašparinova sgiutra dan po Gurgeui. Or. Prikloni

Popa Osipa najkasgni Aprilla. Or. Prikloni

$\mathrm{Na} 24$ Lucie Bosichke za gnu. Or. Molim te

Na 25 Lucie Bosichke druga za cher. Or. Molim te

Na 26 Lucie Bossichke treta. Or. Vernih

$\mathrm{Na} 21$ Gospa Lade. Ora. Molim te 
Maij

Baromigicha na Dugmovu, za popa. Or. Prikloni

$\mathrm{Na} 22$ Gospe Lene na Jellegnu. Or. Molim te

$\mathrm{Na} 24$ Jurgia Jurmanicha cha ie Garzanoua. Ora. Prikloni

$\mathrm{Na} 26$ Kate Mundaricheue. Ora. Vernih

Ellene Zečarice o Duhoui; placha kucha Cimon

Bubich. Or. Molim te

Na 13 Frane Desanticha Ora. Prikloni

Na 7 Popa Vicenca Bataglicha, za popa

Na 1 za Jellu Bukinu. Orat. Molimte Gospodi.

$i$ to plachiaiu eredi pok Iuana Rubchicha

i četiri duplera

Jung

Duminke Kermichichke perui petak po Duhov.i Or. Molim te

7 Jurlicheua ali popa Ferokavcicha. Za popa

12 Mestra Sebicha Mislenouicha. Ora. Prikloni

14 Urse Branisalichke. Ora. Molimte

16 Mikule Fra Gaspara. Ora. Prikloni

20 Mare Albanicichine. Ora. Molim te Gospodi

24 Frane Desanticha. Ora. Prikloni

Lugia

6 Katke Mundaricheue. Ora. Molimte

7 Druga Katke Mundaricheue. Ora. Vernih

20 Vida Valentinicha. Ora. Prikloni

22 Miletkouih. Orat. za mnozih, u S. Francisca

Na 23 druga Miletkouih za mnozih u S. Francisca

Popa Martina na dan S. Panteleona

24 Blasa Zulichicha. ${ }^{46}$ Ora. Prikloni

\author{
Augusta \\ $35 \mathrm{v}$ \\ 10 Gelle Orsiceve. Ora: Molim te \\ 14 Galicina. Ora. Molim te \\ 16 Tomasa Hreglanouicha za Gospu Lenu \\ 23 Frane Ziukovicha. Ora. Prikloni
}

${ }^{46}$ U glagoljskom tekstu: Župičića. 
25 Garzanoua ku ostavi Rimanich. Ora, Prikloni

27 Jurlicheua ku ostaui pop Ferkaucich. Ora. Prikloni

29 Jurgia Mikulanicha. Ora. Prikloni

29 Ivana Katulevicha. Orat. Prikloni

30 Sarcicheua. Orat. Prikloni +

Setembar

10 Mandalene Lovracichke. Ora. Vernih

Nedigle Antona na Mihogliu. Ora. Prikloni

14 Popa Jerka Katridaricha. Ora. Prikloni

15 Pticichkina ili Rade Kouaca. Or. Prikloni

Linardoua na Matignu. Ora. Prikloni

Mare Baracheue na dan S. Mihouilla

14 Vuave Komadinke. Ora. Mollimte

Desantichkina. Ora. Mollim te +

Ohtobar

1 Fumige Palcichke. Ora. Molimte

6 Spaderichkina. Ora. Mollimte

36r

4 Frane Desantichia. Orat. Prikloni

10 Businicina. Orat. Prikloni

22 Pok. uoiuode Matiga Tvardislauicha. Ora. Prikloni

21 Gospe Vice Hreglanouiche. Ora. Mollimte

29 Katarina Mikinichia. Ora. Mollimte

31 Kuanicina. Ora. Mollimte

4 Marka Gerdouicha. Ora. Prikloni

19 Mandalene Lasinouichke. Ora. Mollimte

29 Mihe Rucicha. Ora. Prikloni

Nouembar

3 Mustafichkina. Ora. Vernih

Francisca Ziukouicha na Martignu. Ora. Prikloni

15 Anice chere Andria Kutacichia. Ora. Vernih

4 Pok. gospe Margarite Tuerdislauichke. Ora. Mollimte

15 Kate Lasinouichke Ora. Molimte 
Decembar

Vinka Rupalcicha o Mikugli. Ora. Prikloni

Mileticheua na dan S. Bibigane. Orat. Prikloni

Gospe Lucie Bartulouke na Lucignu plachia kuche. Ora Prikloni

12 Vice Branisaglichia. Ora. Prikloni

\section{Nadarbine oltara}

\section{To su dote Oltara ki su u Segnskoi stolnoj Crikvi S. Marie ${ }^{47}$}

$13 r$

Sueti Iuan jima livella dua: kuća popa Antona

Maletestinića, sada iu darži Anica Bošković-

ka, plaća libre dvi; kuća na potoci go(spo)dina Tomasa Katri-

darića, ka ie sada Iuana Sičića, plaća soldini duaieset (I);

ostanki Franka Zidara plaćaju soldini ceturdeset $(K)$ od magazina

ki je pod crikau. Ostanki Stančić od kućice $i$

vrtla ki e poli crikue, plaća soldini 45 ( $k l)$

Oltar Svetoga Jakova ima livel ki e v dvori Babića

poli murve ku kuću darži sin Matka Veslara. Jošće iednu

zemlu na Pihauici poli zemle Bedričića. Jura iz Ka-

blar plaća od mirišća ko kupi od Babića niže velikih

vrat, plaća soldini 12 (b.i); kuća Krličina plaća soldini 32 (b.d)

Sueta Maria Magdalena ima hižu poli mali zdenac konfin

Blaziol i Miksa Mikulanić; sada drži ju Nouak; plaća soldini 40 (k)

$13 v$

ipred urati mesto ko se affita o Jurjevi i još sada kuću su-

prot sebi ku ie ostavil pokoini Vicenz Desantić. Misu

vsaki petak kapelan.

${ }^{47}$ Izgleda da je stara kvaderna s ovime počinjala. Na početku je arapskim slovima napisana godina 1463. i odmah u prvom retku počinje se s oltarom sv. Ivana. U latiničkom prijepisu sačuvan je cijeli popis oltara. U glagoljskom tekstu nam se, bez naslova, sačuvao samo zadnji dio s oltarima sv. Ivana, sv. Jakova i sv. Marije Magdalene. 


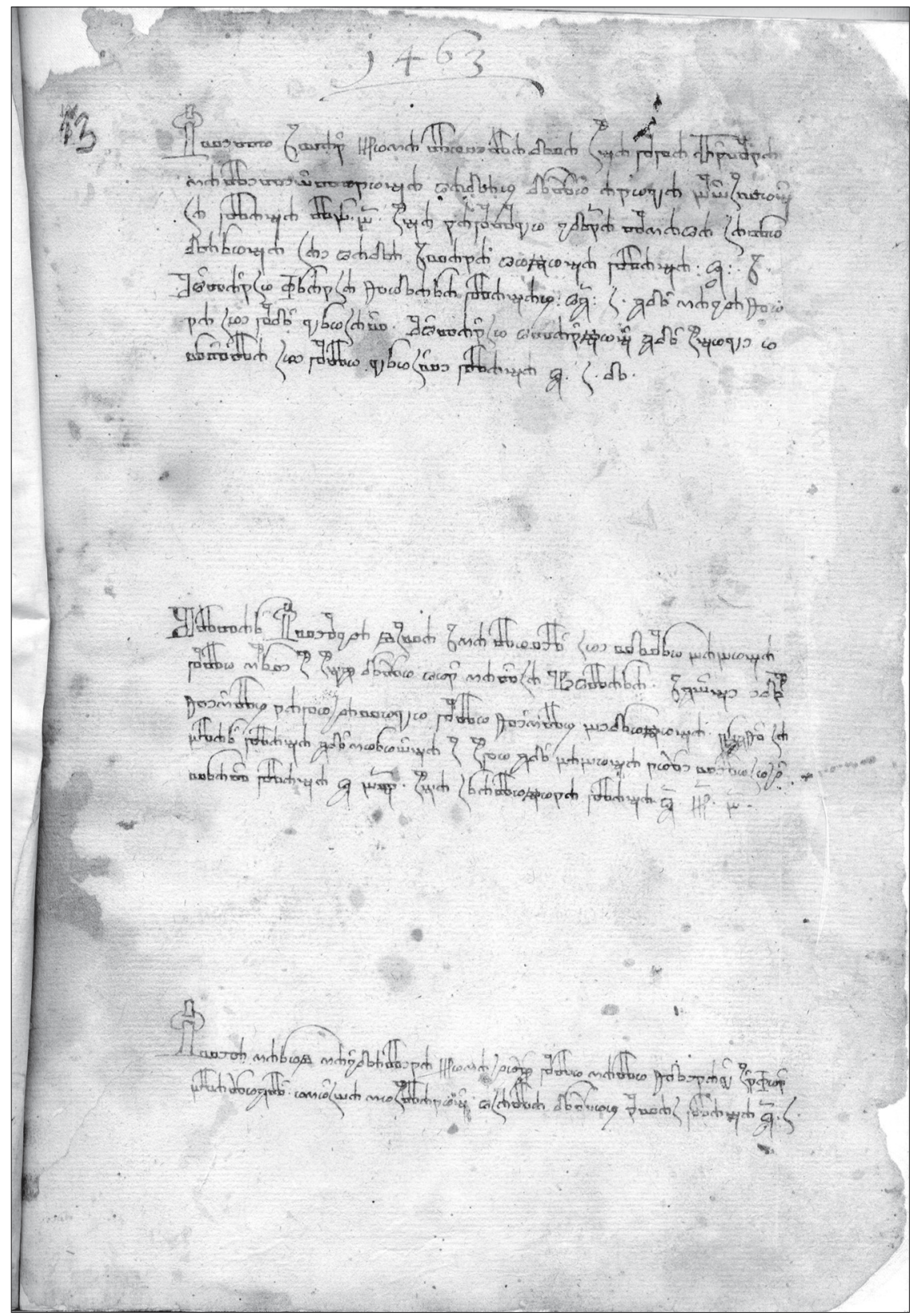

Sl. 7. Faksimil stranice 13r iz Bilježnice ili Kvaderne Senjskog kaptola iz 17. st. (izvor: Biskupski arhiv u Senju) 
$42 \mathrm{v}$

\section{To su dote Oltara ki su u Segnskoi stolnoj Crikvi S. Marie}

Oltar Veliki gima kuchu na Krizi ka se zoue Gallia. Za tu kuchu gouori Kapitul peruu misu suaki pondiglak i sfaku sredu na oltaru uellikom.

Oltar S. Petra gima liuel kuche Giandrigiceue ke su se zualle Cendicha i uertal kige pri kuchi i gima plachat kapitullu soldini 90; igosche uart ki jge bil Sandalicha; gima plachat kapitullu soldini 35; igos kuchu polli kuche Vida Valentinicha i polli kuche ka ie billa polli kuche Mikulle Rubcicha ima misu usredu.

Oltar S. Tome gima iedno mirische kadi ge billa kucha saboenoua kuge darival gdin Mihouil Miletich; igimil ie tarsie uise Suetoga Martina i sada gima uertal pri tersi Juan luckouich, iplacha od gnega ostanki Juana Luckouicha soldini 20 kapitullu.

Oltar S. Kiriaka ima iednu kuchu nize kuche Stacuna Desantich, k moru grede, u koi sada stogi Julliana Kondakouicha i placha od gne kapitullu suako letto o Mihogli libar 12 misu iednu u 2 nedigle kapitul.

Oltar S: Katarine gima kuche dui: iedna ie za kapichem S. Juana, i mirische ko darzi Anica Buskouichka, i placha od gnega kapitullu o Mihogli L 2; i drugu kuchu nize kuche Jurgia Lukacicha. Misu suaki petak kapitul.

Oltar S. Gergura gima pechnicu u kuchi kadi sada stogi pop Paual Billacich, polli kuch Bunicheuich, nasuprot pechnici, a mimo ije put opchinski. I duzan ije kapitul suaki utorak paruu Misu na tom Oltari.

$43 \mathrm{r}$

Oltar S. Antona gima ijednu kuchiu kaije nize kuche Jurigia Blagagicha; plachati gima libre 3 na Antognu. I gedno mirische ko e nize kuche S. Vida Oltara.

Oltar S. Blaza gima iednu kuchu, k moru grede uise kuch kapitulschi barbiria. I zato duzan ije kapitul usuaki petak peruu misu. 
Oltar S. Trogice gima kuchu z duorom, Beruial i Misal i parament. Missa u ponediglak.

Oltar S. Vida ima kuche cetire i ednu ka ije liuelana Herstoforu Bataglicu, a dui poreda nize kuch rupopih acetuarta pri kuchah popa Vincenca Valezicha. Kapitul peruu Missu u pondiglak.

Oltar S. Sebastiana gima iednu kuchu, iedno tarsie i gedan kalez srebarn. Missu suaki catuartak kapitul.

Suetta Ana gima dui kuche: iednu nize uellikih urat pri kuchi Martina Zunicicha, druga na Krizi pri kuchi Louracich. Jedno tarsie uise stana S. Spasa. Mise dui suaki misec.

Sueti Giuan gima livella dua: kucha popa Antona Maletestinicha, sada darzi Anica Boskouicha, placha kapitullu libre dui; kucha na Potoci g(ospo)dina Tomasa Katridaricha, ka ie sada Iuana Sicicha, placha soldini duaieset. Ostanki Franka Zidara placha soldini ceturdeset i pet magazina ki ge pod Crikau. Ostanki Stancich od kuchice i uertla ki e polli crikue, placha soldini 45 .

Oltar S. Jakoua gima liuel ki ge u duori Babica polli murue; ku kuchu darzi sin Matka Veslara. Gosche iednu zemglu na Pihauici polli zemgle Bedricicha Jura iz Kablar placha; od mirischa ko kupi od Babica nize uellikih urat placha soldini 12; kucha Krglicina placha soldini 32 .

Sueta Maria Magdalena gima hizu polli mali zdenac, konfin Blaziol i Miksa Mikuglanich; a sada darzi Nouak. Placha soldini 40 ipred urati mesto ko ie affita. 


\section{Križevi}

\section{Križi kapitula ki plaćaju ${ }^{48}$}

\section{$33 r$}

Križ svete Nedilje plaća Ivaniška libre 2

Križ svete Barbare plaća Ždribčevica libre 2

Križ svetoga Ivana libre 2

Križ svete Margarite libru 1 soldina 7

Križ svetoga Mikule libre 2

Križ svetoga Duminika libre 2

Križ svetoga Petra libre 4

Križ svetoga Roka libre 2

$33 v$

Križ svetih Mladenac libre 2

Križ svete Polonie plaćaju Čeprnini ostanki libre 2

Križ svete Troice libre 2

Križ svetoga Jurja libre 2

Križ svetoga Filipa i Jakova plaćaju Rupovi libre 2

Križ svetoga Jakova i svete Anne plaća kapelan libre 2 od kuć svete Anne

Križ svetoga Antona opata plaćaju kaštaldi libre 2

Križ svetoga Antona Padovana plaćaju kaštaldi libre 2

Križ svetoga Martina plaća libre 2

Križ svetoga Jerolima libre 2

${ }^{48}$ Iz same Kvaderne nije jasno što su "križi", koja je njihova uloga i gdje su se oni nalazili. Činjenica da nisu u 17. stoljeću prepisani na latiničko pismo može značiti da nisu više bili aktualni. Možemo samo pretpostaviti da je svako gradsko područje imalo svoj križ u blizini ili pokraj postojeće crkve, a vjerojatno je bio neki i bez istoimene crkve. Ne zna se, naime, za crkve sv. Nedilje, sv. Dominika, sv. Apolonije, sv. Jakova i sv. Antuna Padovanskog, S druge strane, poznate su nam stare crkve u Senju koje ovdje nemaju svoga križa, kao: sv. Kuzme i Damjana, Sv. Duha, sv. Vida. Najviše začuđuje da se ne spominje križ sv. Franje jer je svakako tada postojala ta crkva (možda zbog blizine sv. Ivana?). U Senju, nedaleko ulice Potok, postoji i danas mjesto koje se zove Križ. Možda je to ostatak tih kvartovskih križeva? 


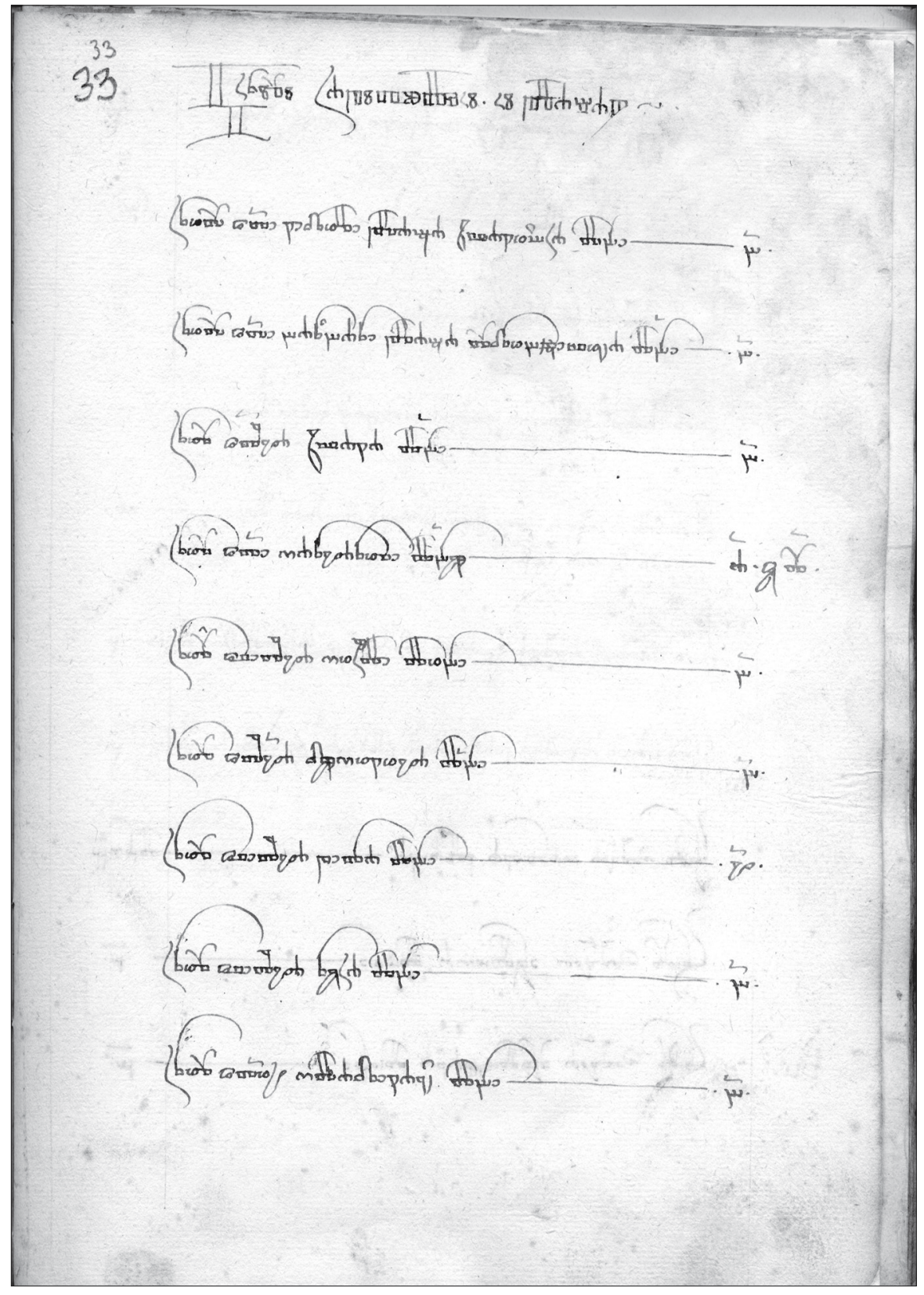

S1. 8. Križevi, faksimil stranice 33r iz Bilježnice ili Kvaderne Senjskog kaptola iz 17. st. (izvor: Biskupski arhiv u Senju) 


\section{Obračuni}

Napomena: Računi i obračuni razbacani su po Kvaderni tako kao da i nije postojalo za njih određeno mjesto. Računi su svi pisani latinicom i arapskim brojevima što znači da pripadaju novijim datumima. Računi su trebali biti podmireni do sv. Mihovila. Oni važniji otvarali su se na dan sv. Jeronima, 30. rujna, ali ima i izuzetaka. Kao i inače, u računima se pazi da se pišu svi brojevi, a riječi se lako preskoče pa je teško popunjavati ispušteno.

2v

\section{Na isti dan Suetogha Jerolima 1669.}

bi afitana kuchia i konoba G(ospo)dinu Arhixakanu Vlatkoviću pri moru kadi sada stoij Petar Cuitich za L 29, koia bi kuchia i konoba naimagne mogla plachati na letto L. 12. To mi puschiamo za zghora receni fitt za gliubau bratinsku do nasse voglie.

Vechie bi afitana konoba prez kuchie spomenutom G(ospo)dinu Arhixaknu pri moru tiskom morskih urat za libar S 60

Vechie bi affitana kuchia ka se zoue Ghalia na krixu knezu Giui Rittaru za L 36, a sada Juriu Bukouzu za duk. 8, S. 36

Vechie bi affitana kuchia u ghorgnemu kraiju Paui Petrouichu za S. 24

Vechie bi affitana kuchicza malla Mikiczi Balinouichiu za S. 16

Vechie bi affitana kuchia Jurissi Balinouichiu kadije stal pokoini pop Paual Miossich za S. 30

$3 r$

Vechie bi affitana kuchia G(ospo)dinu Can(oniku)u Pietru Spingharolichiu za S. 24 kadi sada stoi Mihel.

Vechie bi affitana kuchia, kadi je stal pop Juka, Mandi Tintorouoij za S. 36 u koi sada stoij Xiuichieu sin.

Vechie bi affitana kuchia Anti Cubranki za libar S. 18

Vechie bi affitana kuchia Matiu Xarkouichiu za (?)

Vechie bi affitana kuchia Marku Malessichu za S. 18

$3 v$.

Neka dugovanja Kaptolu,

$\mathrm{Na}$ dan Svetogha Mihovilla Racbolt osta dusan fit cist.

Iuan Racbolt ucini racun do dan Svetogha Mihouilla 1670. i osta duxan od kuche u koi stoi kako se u ceduli uzdarxi

S .14

Bi ucignen racun do dan S. Mihouilla 1670. Iuanom Perkarichem, i osta duxan S. $3: 10$ 
Bi ucignen racun s Mikom Balinouichem do prosassne Mihoglie i osta duxan S. 4

Paue Petrouich polak racuna osta duxan do prosasne Mihoglie

$7 \mathbf{v}$

Popisa nekih prihoda (nečitljivo)

Gospodinu Arhizakan od .... ditze S. 14

Item od konobe ku derse $\quad$ S. 20 (dalje nečitljivo)

8rv (nečitljivo)

$9 \mathrm{r}$

Na 22. Augusta 1667.

Buduchi obrani za sucze arbitre od iedne i drughe strane, a tto g(ospodi)n Arhixakan pop Mihovila Wllatkovicha i Petra Lucichia i go(spodi)n Plovan pop Mihovil Desantich, g. pop Matig Celovich i Voiuoda Frane fon Aklibergh, knez Jure Radich, a to za uzrok ca potribuie spomenuti knez Petar od g(ospodi)na Arhixakna

(dosta teksta križano i nečitljivo)

9v

Na 2. Februar1570.

Stauismo u nassu kuchu Antona Hrikustana doli ... placha S.30 suako letto ....

Na 8. Marcia 1670. stavismo v kuchi Juana Pecharicha v koie stal pok. pop Massich placha vsako letto S. 30

Iuan Racbokt placha na letto na pechniczu S.24 a poide u gnu na 12 Maiia

Martinaz Mikilou poide u kuchu pri G(ospodi)nu Tomi Hreglanouich na 2 Juna 1670. i placha na letto fitta S 27

10 rv

Na 29 7tembra 1676,

(nečitljivo i iskrižano). Spominju se Jurica Poljičan, Mateša Matijašević i Vule Balenović, Vule Ručić, Mate Juršić, Mara Škarić, Jela Domazetović i Cvita Radivojević....

$11 \mathrm{v}$

Na 18. fervara 1672.

Učini račun Miho Radivoievich i osta duxan S. 13

Veche osta duxan Luka Stuz do 13. Maija 1671.

U ostalom prekriženom i slabo čutljivom tekstu spominju se Mara Škarić i Jela Domazetović, Vlatko Vahtar. 
$12 \mathrm{r}$

Na 18. gennara 1672. Bi ucinnen racun od dana danassgnegha knez (prekriženo) do 9. Maija 1672. knezom Mattessom Mattijassevichom i knezom Juriczom bratom gneghovim i osta suaki duxan na del svoj od pol kuche na ku placa Juruicza (polovicu) na letto, a Mattessa na drughe pol livella po L 18 ca je u sve 36 - kako nato imiu cedule.

$\mathrm{Na}$ 18. Jennara 1672. bi ucignen racun s knezom

Juriczom Danchichem od livella izbatnussi (?)

ca ie meni dal S 1 i : 4. i osta duxan S. 10: 6

Na 18. Aprilla 1673. bi ucignen racun knesza Vukom Ruci-

chen od livella koga plachaiu na kukignica gnih sa svako letto S. 1: (?)

$\mathrm{i}$ bi prijeta u racun quiettancia pok. popa Iuana Kognikovicha

ka e ucinen na 20. settembra 1646. i vise toga prigese pok. pop

Iuan J 10 zbatausi(!) recena quietancia ostasse duxni Libre dvadset

$12 \mathrm{v}$

Na 6. Oktobra 1674.

Na dan danassgni pogodise poss(tovani) Kaptol G(ospodi)nom Arhixakanom Wlatkovicem i da se go(spo)din Arhixakan na gnihov porcion od kuch kapitulskih pechnizu i konobu pod Hirkusom(!) na gnihovi del samo da g(ospo) din Arhixakan od 40 govora(!) S. 10 a frabike ki se budu cinili koliko P. Kapitul koliko i g. Arhixakan budi dusni skupa nacignati.

$37 \mathbf{v}$

Jurgia Katredarchia 230 naguonduom (?) sedm

Dumenka xena pok. Iuana Vodopie sedmo

Iuan Bogdesich u drazi za kuchiu Lukichu (prekriženo)

Antona Antabela (nejasno!) za kuchiu Lukichia (prekriženo pa dodano) za kuchiu Lukichia

neku ku ostaui Frane Desantich gednu Misu u Parki uziua Matig Desantich i sestra gnegoua Katarina kuchia ie mirischie uise puta a bragda uise puta kud se gre gospogi.

J $44444(?)$

$1680(?)$

1680. Dodano glagoljicom: abdofggi (?) 
$38 \mathrm{v}$

Mate Papeslo placha na kuchiu ka ie suprot kuchi kapitulskoi pri kuchi pok. popa Jurgia Boguticha od giuga suako leto

S. 3

Dva Bratta Matiasevicha Jurica i Matesa plachiaiju kapitullu suako letto od kuche u koi oni stoge.

Matesa iednu a fratrom S. Francisca S. 3

$58 \mathrm{v}$

Jedan račun iz 1676.

...1 bila liuelana Matei Jursichiu.....dreua ie isrucil suoioi.... a seni Iue Wdragouichiu na ku kuchu placha suako leto po S. 30

Na 297 bra 1676

$59 \mathrm{~V}$

Na 1 Luia 1668 bi ucignen racun Lukom Stucem od kuche u koi stogi posue letto 1668 do 9 Maia na ku kuchu placha libar deuet suako letto liuella dim S. 9 i osta duzan do 9 Maia 1 letta kako zgora liber 25 dim duaiset ipet sol:10. Kucha ie za kapichem S. Juana, kako se uzdarzi u staroi quaderni kaie kucha dana stim patom i kondicigonom dase gima $u$ dobru redu darsat daie Post. Capitul predaie uazme.

$\mathrm{Na} 1$ Luia 1668 bi ucigen racun k Juanom Luckinichem u sakrastegi Sgnskoi od kuche ukoi stogi na ku placha suako letto na dan S. Mihouilla liuela libar $\operatorname{dim}$

S. 6

I osta duzan do ultim setembra letta kako zgora osamnaest din

S. 18 60r

Na 2 Lugia 1668 bi ucigen racun Josefom Heruinom od kuche u koi stogi, ka kucha placha livella Postouanomu Kapitullu Segnskomu libre tri suako letto na dan Suetoga Mihovilla dim S. 3 i osta dusan receni Josef do ultima setembra letta kako zgora libar trinaist dim S. 13

Na 26 Jugna 1668

$\mathrm{Na} 21$ Settembra 1668 bi ucigen racun knezom Matom Jursichem od kuche suprot kuchi kapitulskoi kou oni uziuaiu. I osta duzan do 21 settembra letta kako zgora S. 6, kako nato cedulu gimaiu.

Na ultim Januara 1669 bi ucigen racun knezom Matom Vahtarom od kuche u koi stogi na ku placha suako letto S. 2 liuella. I osta duzan praua racuna do 10 aprilla 1699 libar sest dim

S. 6 
$63 \mathrm{r}$

Na 2 8bra 1679.

Bi ucignen rachun Marom Skarichkom i plati luell posteno posue letto kako zgora.

$\mathrm{Na} 2$ 8bra 1679. bi uchignen rachun gospodinom popom Juricom ...... od mirischia i od kuche Kloricheue i plati liuel posue letto kako zgora. (ovo je iskrižano!)

\section{9. Četiri ugovora o najmu kuća ${ }^{49}$}

$75 \mathrm{r}$

Senj, Oko 1600. godine, Senjski kaptol daje neku kuću arhiđakonu senjskom Dumku Miletiću pod određenim uvjetima.

(nedostaje prvi dio)

Zato mi procinivši spodobnu prošnnu nihovu tolikajše obećane ostalo i da je ta naša kuća u zlu termenu i rujinana

i na markament došla koju nas pitaju e da ju ne bi dosta pinez načinili, i pače za pirikulu da bi mogla ereda doli pasti, a mi za uzrok uboštva i potribušćine ne imajuć iju čim načiniti, za zavši ${ }^{50}$ mi meju nas našega prakuratura kneza Jivana Marinića, bohmeštra senjskoga, i dogovoriše se š nim, s volom i znaniem našega presvitloga g(ospo)d(in)a biskupa ${ }^{51,}$ i procinivši kako zgora prošnu spodobnu i obećanie da nam oće veća korist a ne škoda biti.

Zato determinasmo i odlučismo dati, i dasmo rečenu kuću našu sa vsim pristojaniem, ča nu udostoji rečenomu gospodinu arhižakanu , popu Dumku Miletiću i nihovu bratu Vidu Miletiću i nihovim ostankom va veki terpeći, $i$ da jesu oni sada od rečene kuće pravi i stanoviti gospodari, i zvati se mogu i budu, te od sada oni i jnihovi ostanki volni rečenu kuću od sada i na pridak uživati, posediti, radovati, dati, darovati, prodati, prominiti $i$ za dušu ostaviti $i$ čagodar j nim i nihovim ostankom

${ }^{49} \mathrm{Na}$ kraju Kvaderne nalazi se prijepis glagoljicom četiri kaptolska ugovora o iznajmljivanju kuća ("inštrumenti"). Izdani su početkom 17. stoljeća, a prepisani u vrijeme biskupa Agatića 1625. godine. Od tih prijepisa nisu svi sačuvani. To se vidi iz toga što u jednom dokumentu nedostaje prvi dio. Te dokumente je teže čitati nego prethodne glagoljske tekstove jer imaju neke svoje osobitosti u pisanju kurzivne glagoljice.

${ }^{50}$ Treba: zazvavši.

${ }^{51}$ Senjskom biskupijom je tada službeno upravljao Markantun de Dominis. On je 16. studenoga 1602. imenovan splitskim nadbiskupom. 
od rečene kuće drago budi učiniti, kako od stvari nihove i vlastovite, va veki terpeći, slobodu i franku i pače sada nu kapitul senski oni obligacion koji bil na toi kući ku mi nim izručujemo i zimlemo ga van i ostavlamo na one kuće kie oni nam izručiše slobodne i franke, tako da se razumi rena(!) kuća libera slobodna i franka brez niednoga obligaciona.

Čineći mi za nas sadanih i naprid budućih ovu prominbu od zgora kuć stanovitu moćno i kripko obderžati i mantinati i ne opogovoriti po pravdi, ni po delu ni malu ni veliku, vazimljući na nas sentenciju dobro volom pod obligacion jedne i druge strane naših mobil i stabil ovu preminbu od zgora jimenova

$75 \mathrm{v}$

zgora imennovanoga gospodina arhižakna i negva brata Vida i nihove eredii, tolikajše oni nas braniti oda vsake verste ludi duhovnih ali telesnih inim, ali nam ki bi se va vomu otili suprotiviti, i za veće vekovania i kriposti, mi kanonici sadanega vremena kapitula senskoga na ovi ispromenov naša imena i pridivak našimi vlastovitimi rukami podpisasmo i zapečatismo našim velikim pečatom kapitulskim. Dan u Sejnu u našoj sakrestiji, miseca i leta kako zgora. Ja pop Matij Belić plovan i kanonik crkve senske oblastju cesarsku notar očiti i kanciler kapitulski pisah ov instrument moiom rukom vlašćum, s voljom i ordinom zgora imenovanoga kapitula $i$ bratie $i$ za veće verovanie na ov instrument moije jime i na vani sinal jesam postavil. i pritom biše na svidočastu va Isukarstu pop dom Bartul Vlahović od Verbnika, i knez Juraj Daničić i knez Jivan Hrelanović , vlastelin senski.

Pop Mikula Ljubičić kako zgora

Pop Paval Bilačić, tverdim

Pop Paval Miovčić, tverdim

Pop Stipan Biljević, tverdim

Pop Jandrija Poplaković

i ja Jivan Marinić, prokurator bih pritom

Netko iz pratnje senjskog biskupa Ivana Krstitelja Agatića je uz to dopisao (lošim) talijanskim jezikom, što je biskup potpisao: Essendo la supra skrita permuta con evidente utile della S. Chiesa per tanto Mons(igno)r Ill(ustrissi)mo et R(evereddissi)mo 


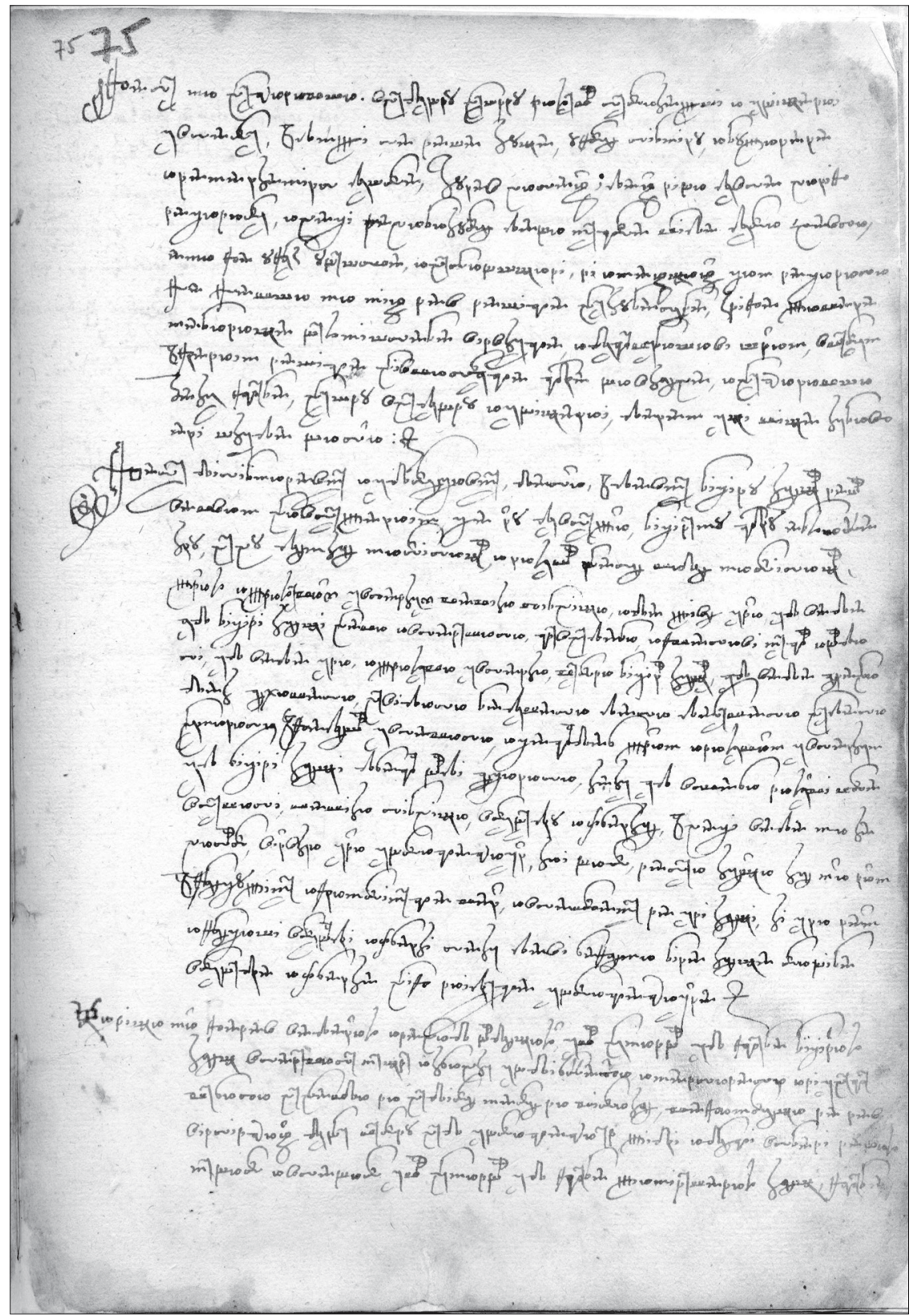

S1. 9. Faksimil stranice 75v iz Bilježnice ili Kvaderne Senjskog kaptola iz 17. st. (izvor: Biskupski arhiv u Senju) 
la confirmata et coroborata il 29. ottobra 1625.

Nečitljiv potpis

Locus G. Io. Bap. ep.us Segn. ${ }^{52}$

sijlij

$76 \mathrm{v}$

Senj, 1. rujna 1603. Senjski kaptol daje svoju kuću koja se zove Galija Jandri Moniginu.

1603. miseca setembra na prvi ...

Sudac Jeronim Veronez i knez Andrij Miletić prakaraturi

kapitulski zaedno sa vsim kapitulom dasmo kuću našu kapitulsku ka se zove Galija Jandri Moniginu s ovim patom. da do deset let kuću uživa on, negovi ostanak i da plaćaju od jinei ili zabadvaju (!) u jime načinbe vsako leto tri dukata ča ih fita 100. Nakon tih deset let da se račun vidi i ako se najde ča veći potroška na kući, da e kapitul platio Jandri ili negovim, ako ne budu otili v kuću stati. Ako li budu otili stati u kući da im se nakon tih deset let jedan udoban fit postavi i ono ča bude od više u fit zbata ili pak on ili negovi ostanki po nem plaćajući počteno vsako leto fit na ki se meju sobu nakon deset let od sada pogode, da kapitul Jandru ni negovih ostanak ne mozti s kuće gonit do nih vole, nego s tim patom ako bi vsako leto fit ni plati, ili nakon leta, tada kapitul mozi nih van dati $i$ staviti koga mu drago. I jošs tim patom da Jandre vse stvari od krova potrebne načiniti, a pak od sada iliti od danas imij načiniti kemu kapitul oće dobre učiniti nakon deset let kako e gore rečeno i da vsako leto ima kapitulu račun pokazati ča ko va to strati, Ako li pak Jandre fali i krova ne načini do mladoga leta, ipak ostale stvari potribne do termina, kako e zgora rečeno, te se kuća ili pade ili na ki mankament pride da zato imij Jandre kapitu-

${ }^{52}$ Agatić se ovdje ne potpisuje i kao modruški biskup što bi moglo značiti da još nije bilo formalno sjedinjenje Senjske i Modruške biskupije pod upravu istog biskupa. 
lu odgovoriti i nato se kuntenta i kuću mu izruči So(ldini) 40 (k).

Dan u leto ko i i zgora a to na Cimiteri.

1603 na 2. oktobra pušćaše kapitul na lbr 17.

V sekrestiji pred prokaraturi zgora imenovanimi

Pop Juraj Bogutić arhižakan

vikar pisa

$77 \mathrm{r}$

Senj, 8. listopada 1603., Senjski kaptol potvrđuje da je

Jandre Monigin platio najam kaptolske kuće

1603., miseca oktobra na dan 8.

pred prakaraturi kapitulskimi gospodinom Jero-

nimom Veronezom i knezom Andriem Miletićem

i na svedočastvo knez Vicko Lovračić i fra

Frane Turčić, pop Matij Hrelanović i pop

Paval Bilačić v kući imenovano i uči

nismo račun s Jandrom Moniginom ča e pla-

til v kuću i naidosmo čist račun da e

platil libar sto $i$ četrdeset $i$ soldi-

ni sedam dim lbr 140 so. 7

i ja pop Juraj Bogutić arhižakan i vikar

crikve senske zaedno s gore imenovanimi

bih pritom i to pisah rukom moju vlašću.

$77 v$

U Senju, oko 1600. Senjski kaptol iznajmljuje Kati Stoislavki

kuću oltara sv. Katarine

Sudac Jerolim Veronez i knez Jandrija Miletić

prokuratori kapitulski zaedno sa vsim kapi-

tulom dasmo kuću našu kapitulsku ka se zove

kuća Ste Katarine oltara niže kuće Jurja Luka-

čića Kati Stoislavki s ovim patom da do

deset let kuću uživa, ona i jne ostanki, i da

plaćaju od jne ili zbativaju, ujime način- 
ne vsako leto libar 8 nakon tih deset let da se računi vide i ako se najede ča već potroškah na kuću da ije kapitul plati Kati ili jne ostankom, ako ne budu otili stati, abi oteli stati f kući da j nim se nakon tih deset let jedan podoban fit postavi $i$ ono ča bude od više u fit sbatem i da pak ona ili jne ostanki po jnoj plaćajuće posteno vsako leto fit meju sobu nakon 10 let od sada pogode da kapitul Katu ni ne ostanak ne mozi s kuće goniti, do nih vole, nego s tim patom ako bi vsako leto fit ne platiti ili nakon leta kapitul mozi jnih van dati i staviti koga ти drago.

\section{Zaključak}

U Senju se nije sačuvao nijedan glagoljski rukopisni kodeks kao niti jedna glagoljska knjiga iz vremena ranog tiskarstva, čak ni iz hrvatskih glagoljskih tiskara u Senju i Rijeci. To nije znak da ih u Senju nije bilo, nego da su korištene dok nisu do kraja iskorištene. Svakako je u Biskupiji i u Kaptolu glagoljica bila uz latinicu službeno pismo. Do sredine 17. stoljeća Senjski kaptol je svoje službene knjige pisao glagoljicom. U Kaptolskom arhivu u Senju sačuvana nam je službena, rukopisna knjiga iz 17. stoljeća, pisana kurzivnom glagoljicom s kojom se u knjizi miješa i latinica $i$ to na taj način da je dio pisan samo glagoljicom, dio samo latinicom, a dio jednim i drugim pismom. No, upravo $\mathrm{u}$ to vrijeme prelazi se s glagoljice na latinicu. Knjiga je slična kvadernama drugih kaptola u to vrijeme. Knjiga je ovdje donesena u cijelosti i nazvali smo je jednostavno - Bilježnica. Ono što je pisano latinicom preneseno je u originalu, a ono što je pisano glagoljicom preneseno je u transkripciji. Da bi se mogla napraviti potrebna usporedba tekstova i pojedinih riječi, priložene su preslike izabranih stranica kako u glagoljici tako i u latinici. Tako se lakše može pratiti prijelaz kaptola s glagoljice na latinicu.

Bilježnica nam bolje nego koji drugi spis daje vjernu sliku Senja u 17. stoljeću, kao i društvene i crkvene prilike u tom biskupijskom gradu, u vrijeme kada je senjsko-modruški biskup boravio u slobodnom dijelu Modruške biskupije, a Senjska biskupija spala na jednu (senjsku) župu kojom je upravljao 
kaptol. Krajem istoga stoljeća Senju je porasla važnost jer se biskup vratio u nj, a njegova jurisdikcija protegnula se na široki prostor koji je oslobođen od Turaka.

Bilježnica je također korisna za upoznavanje pojedinih crkava u Senju i crkvenih udruga pri njima. To osobito vrijedi za Katedralu. Spominju se mnogi lokaliteti tako da se i iz ovog dokumenta može približno rekonstruirati urbanistički izgled grada. U Bilježnici se spominje većina obitelji i prezimena koja su postojala u Senju.

Izvori i literatura

I. Izvori

Arhiv HAZU IId 125

Arhiv Hrvatskog državnog arhiva Zagreb, Protokoli 15, f, 8v.

Biskupski arhiv Senj (BAS), R3, 29

Kaptolski arhiv Senj:

Kvaderna Senjskog kaptola, Knjige, br. 2.

Spomenica kaptola i župe i župe u Senju (neregistrirana)

\section{Knjige i članci}

Anđelko BADURINA, "DATJA" i "PRIJATJA" trećoredskih samostana kao izvor za gospodarsku povijest Cresa i Lošinja, Otočki ljetopis Cres-Lošinj, 5, Mali Lošinj, 1984, 1-176.

Mile BOGOVIĆ, Crkvene prilike u Senju u 14. stoljeću i Statut senjskog kaptola, Senjski zbornik, 15, Senj, 1988, 15-28.

Mile BOGOVIĆ, Prijelazno stoljeće senjske Crkve (1450. - 1550.), Senjski zbornik, 17, Senj, 1990, 69-92.

Mile BOGOVIĆ, Senjsko-modruška ili krbavska biskupija: izvješća biskupa Svetoj stolici 1602. - 1919., Zagreb, 2003.

Mile BOGOVIĆ, Moji predšasnici biskupi u Senju, Otočcu, Krbavi, Modrušu, Vinodolu i Rijeci, Senj, 2017.

Josip BURIĆ, Biskupije Senjska i Modruška u XVIII. stoljeću, Zagreb - Gospić, 2002.

Daniele FARLATI, Illyricum sacrum, IV, Venetiis, 1769.

Ante GULIN, Hrvatska crkvena srednjovjekovna sfragistika, Zagreb, 1998.

Ante GULIN, Hrvatski srednjovjekovni kaptoli, Zagreb, 2008.

Vladimir KRALJIĆ, Popis arhivske građe Biskupije i Kaptola u Senju, Vjesnik Historijskog arhiva u Rijeci i Pazinu, XX (1975. - 1976.), 231-299; XXI (1977.), 311-350; XXII (1978.), 165-201.

Enver LJUBOVIĆ, Grbovnik Gacke, Krbave, Like, Senja i Vinodola, Senj, 2007. 
Mile MAGDIĆ, Popis patricijskih i građanskih porodica senjskih od godine 1758. Starine JAZU, 17, 1885, 49-53.

Marko MEDVED, Augustinci pustinjaci u Senju, Senjski zbornik, 42-43, Senj, 2015, 443-452.

Manojlo SLADOVIĆ, Povêsti biskupijah senjske i modruške ili krbavske, Trst, 1856. (pretisak: Gospić, 2003.).

Damir VIŠKANIĆ, Quaderna Capituli Lovranensis - Kvaderna Kapitula lovranskog, Luvran - Rijeka, 2002.

\section{NOTEBOOK OF THE SENJ CHAPTER FROM THE $17^{\text {TH }}$ CENTURY}

\section{Summary}

In the Bishop's archive in Senj there is a handwritten book of the income of the Senj Chapter from the $17^{\text {th }}$ century. It is written in Glagolitic italic and Latin scripts. In the book can be followed the social and ecclesiastical conditions in this diocesan town at the time when the Senj-Modrus bishop lived in the free part of the Modruš diocese, and the Senj diocese belonged to one (Senj) parish which was governed by the Chapter. At the end of the same century, Senj as a diocesan centre would grow in importance because the bishop returned to it, and his jurisdiction would extend over the wider area which was liberated from the Turks.

Keywords: book of income, Senj Chapter, Bishop's archive 